\title{
Estimating Recharge to Ground Water from Precipitation at Naval Submarine Base Bangor and Vicinity, Kitsap County, Washington
}

U.S. Department of the Interior

U.S. Geological Survey

Water-Resources Investigations Report 01-4110 


\section{Estimating Recharge to Ground Water from Precipitation at Naval Submarine Base Bangor and Vicinity, Kitsap County, Washington}

By W.R. Bidlake and K.L. Payne

U.S. GEOLOGICAL SURVEY

Water-Resources Investigations Report 01-4110

Prepared in cooperation with DEPARTMENT OF THE NAVY

ENGINEERING FIELD ACTIVITY, NORTHWEST

NAVAL FACILITIES ENGINEERING COMMAND 


\title{
U.S. DEPARTMENT OF THE INTERIOR GALE A. NORTON, Secretary
}

\author{
U.S. GEOLOGICAL SURVEY
}

Charles G. Groat, Director

Any use of trade, product, or firm names in this publication is for descriptive purposes only and does not imply endorsement by the U.S. Government.

For additional information write to:

District Chief

U.S. Geological Survey

1201 Pacific Avenue - Suite 600

Tacoma, Washington 98402

http://wa.water.usgs.gov
Copies of this report can be purchased from:

U.S. Geological Survey

Information Services

Box 25286, Federal Center

Denver, CO 80225-0286 


\section{CONTENTS}

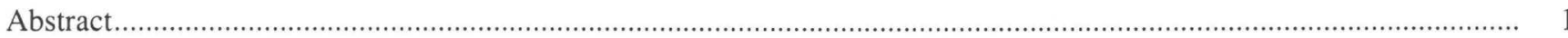

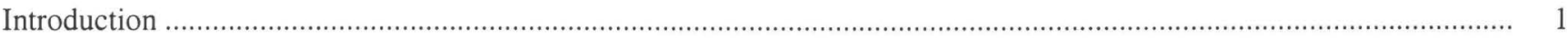

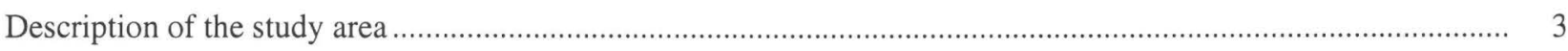

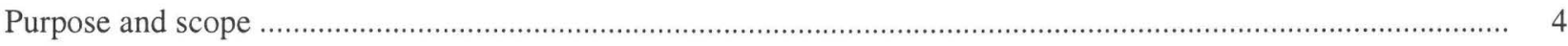

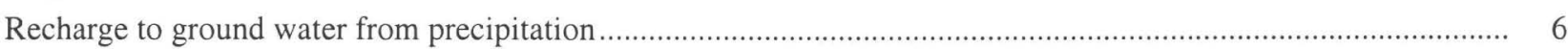

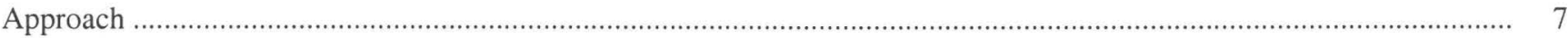

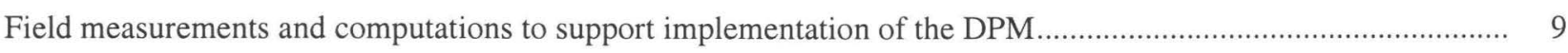

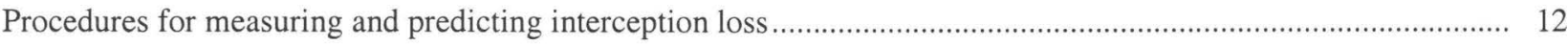

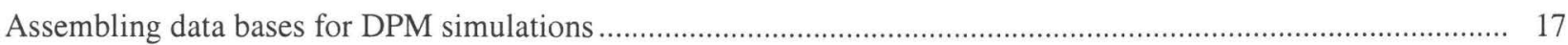

Simulated and measured water-balance components for the water-balance intensive study areas .................................. 21

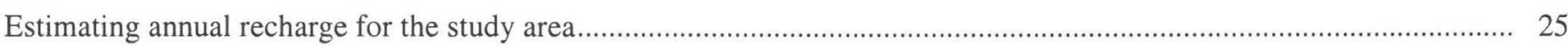

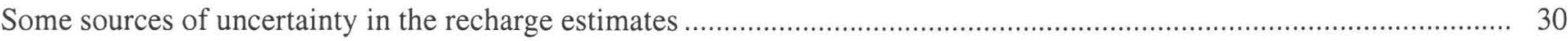

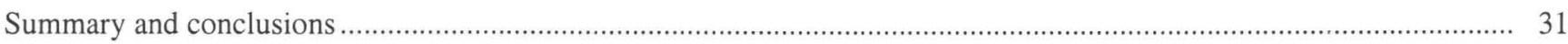

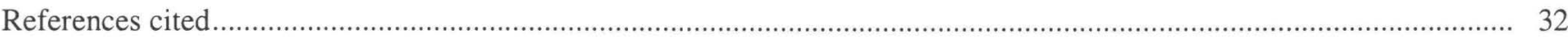

\section{FIGURES}

1. Map showing northern Kitsap Peninsula and the study area

2. Map showing stream-gaging and meteorological stations, soil-water storage and forest throughfall measurement sites, and the water-balance intensive study areas.

3-10. Graphs showing:

3. Total stream discharge and base flow for streams used for estimating direct runoff from the water-balance intensive study areas

4. Seven-day average of daily solar radiation and daily maximum and minimum air temperature, and 7-day total of precipitation as measured at the Cattail meteorological station

5. Total storm throughfall and total storm precipitation for odd-numbered storms with total storm precipitation of less than 0.4 inches during January 1, 1995 to March 31, 1996

6. Cumulative precipitation, cumulative precipitation minus cumulative throughfall, and cumulative throughfall during the initial hours of five different storms

7. Cumulative precipitation, cumulative measured interception loss, and cumulative predicted interception loss for January 1, 1995 to March 31, 1996

8. Monthly precipitation and simulated drainage from the root zone, averaged among soil and land-cover types for the four water-balance intensive study areas, and expressed as a fraction of the 12-month average

9. Measured and simulated soil-water storage for a site within the Upper Johnson Creek water-balance intensive study area during August 1, 1994 to March 31, 1996

10. Annual recharge for selected combinations of soil and land-cover types, annual precipitation, and lines depicting relations between annual recharge and annual precipitation

11. Map showing soil and land-cover groups and precipitation zones.....

12. Map showing long-term average annual recharge in inches per year, based on average annual precipitation at Bremerton during 1953 to 1995 . 


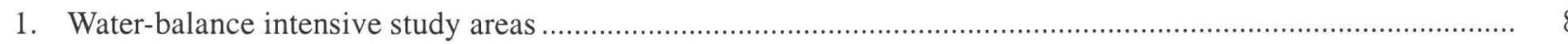

2. Water-balance components computed in conjunction with Deep Percolation Model simulations of the nearsurface water balance of the water-balance intensive study areas.

3. Soil-water storage as measured at four stations in the Upper Johnson Creek water-balance intensive study area

4. Relations for predicting annual recharge to ground water from annual precipitation

5. Measured and estimated annual precipitation at Bremerton for calendar years 1953 to 1995

CONVERSION FACTORS, VERTICAL DATUM, SYMBOLS, and ABBREVIATIONS

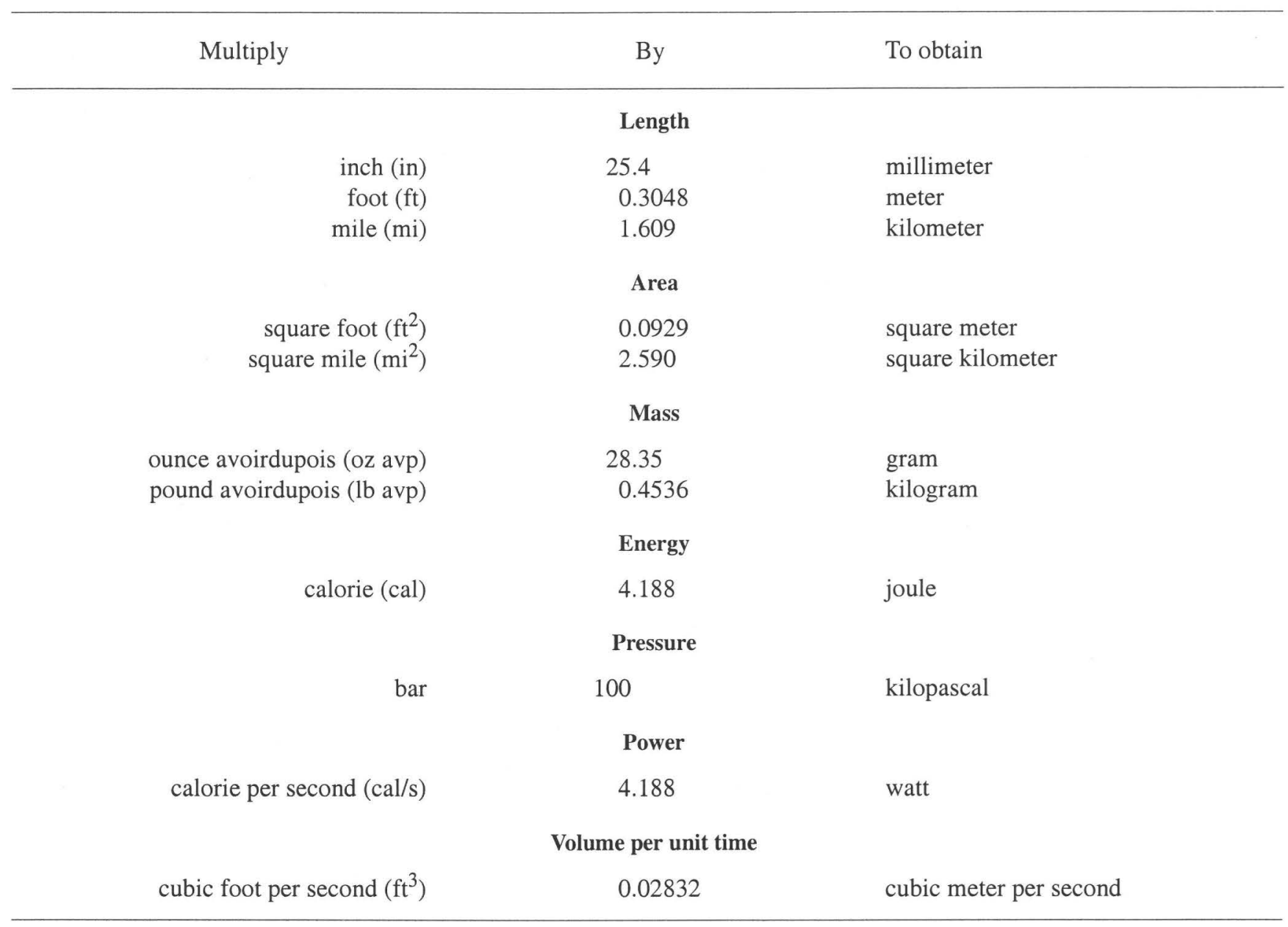

Temperature: To convert temperature given in this report in degrees Celsius $\left({ }^{\circ} \mathrm{C}\right)$ to degrees Fahrenheit $\left({ }^{\circ} \mathrm{F}\right)$, use the following formula: ${ }^{\circ} \mathrm{F}=\left(1.8 \times{ }^{\circ} \mathrm{C}\right)+32$.

To convert temperature given in this report in kelvins $(\mathrm{K})$ to degrees Fahrenheit $\left({ }^{\circ} \mathrm{F}\right)$, use the following formula: ${ }^{\circ} \mathrm{F}=(1.8 \times \mathrm{K})-459.7$.

Sea Level: In this report "sea level" refers to the National Geodetic Vertical Datum of 1929 (NGVD of 1929)—a geodetic datum derived from a general adjustment of the first-order level nets of both the United States and Canada, formerly called Sea Level Datum of 1929. 


\begin{tabular}{|c|c|c|}
\hline Symbol & Meaning & Dimensions \\
\hline $\mathrm{A}_{\mathrm{Q}}$ & Drainage basin area contributing to direct runoff & $\mathrm{ft}^{2}$ \\
\hline$a_{s}$ & Reflectivity of the forest canopy to short-wave radiation & dimensionless \\
\hline $\mathrm{C}$ & Factor to convert from meters per second to inches per day & in. $s /[\mathrm{m} \mathrm{d}]$ \\
\hline$c_{p}$ & Specific heat of air at constant pressure & $\mathrm{J} /[\mathrm{g} \mathrm{K}]$ \\
\hline $\mathrm{D}$ & Rate of downward flow of water at the reference level & $\mathrm{in} / \mathrm{d}$ \\
\hline $\mathrm{D}_{\mathrm{r}}$ & Rate of drip of meteoric water from canopy surfaces to the forest floor & $\mathrm{in} / \mathrm{d}$ \\
\hline $\mathrm{E}_{\mathrm{i}}$ & $\begin{array}{l}\text { Rate of evaporation from plant surfaces of precipitation that has been } \\
\text { intercepted and stored on those surfaces }\end{array}$ & $\mathrm{in} / \mathrm{d}$ \\
\hline$E_{p}$ & Potential evaporation rate & $\mathrm{in} / \mathrm{d}$ \\
\hline$E_{s}$ & Rate of evaporation from soil surfaces & $\mathrm{in} / \mathrm{d}$ \\
\hline $\mathrm{E}_{\mathrm{t}}$ & Rate of plant transpiration & $\mathrm{in} / \mathrm{d}$ \\
\hline $\mathrm{e}_{\mathrm{a}}$ & Atmospheric water-vapor-pressure & $\mathrm{kPa}$ \\
\hline $\mathrm{e}_{\mathrm{s}}$ & Atmospheric water-vapor-pressure at saturation & $\mathrm{kPa}$ \\
\hline j & $\begin{array}{l}\text { Time-step index, where } \mathrm{j} \text { represents the current time step and } \mathrm{j}-1 \text { represents the } \\
\text { most recent time step }\end{array}$ & dimensionless \\
\hline $\mathrm{L}$ & Thickness of the unsaturated soil & $\mathrm{ft}$ \\
\hline $\mathrm{P}$ & Precipitation rate & $\mathrm{in} / \mathrm{d}$ \\
\hline Q & Stream discharge & $\mathrm{ft}^{3} / \mathrm{s}$ \\
\hline $\mathrm{Q}_{\mathrm{b}}$ & Base flow discharge & $\mathrm{ft}^{3} / \mathrm{s}$ \\
\hline $\mathrm{R}$ & Recharge rate & in/yr \\
\hline $\mathrm{R}_{\mathrm{o}}$ & Direct runoff rate per unit of land area & $\mathrm{in} / \mathrm{d}$ \\
\hline $\mathrm{r}_{\mathrm{a}}$ & $\begin{array}{l}\text { Aerodynamic resistance to transport of scalar quantities between the forest canopy } \\
\text { and the atmosphere }\end{array}$ & $\mathrm{s} / \mathrm{m}$ \\
\hline$r_{e}$ & $\begin{array}{l}\text { Parallel equivalent resistance to exchange of sensible heat and long-wave } \\
\text { radiative energy between the atmosphere and the forest canopy }\end{array}$ & $\mathrm{s} / \mathrm{m}$ \\
\hline$r_{r}$ & $\begin{array}{l}\text { Coefficient that accounts for response of the canopy long-wave radiation balance } \\
\text { to the canopy-to-atmosphere temperature difference }\end{array}$ & $\mathrm{s} / \mathrm{m}$ \\
\hline $\mathrm{S}_{\mathrm{c}}$ & Amount of water stored by the canopy & in. \\
\hline $\mathrm{S}_{\mathrm{cm}}$ & Canopy water storage capacity & in. \\
\hline$S_{t}$ & Flux density of incoming short-wave radiation & $\mathrm{W} / \mathrm{m}^{2}$ \\
\hline s & $\begin{array}{l}\text { Slope of the relation between the vapor-pressure of water-saturated air and } \\
\text { temperature }\end{array}$ & $\mathrm{kPa} / \mathrm{K}$ \\
\hline $\mathrm{T}$ & Travel time & $\mathrm{yr}$ \\
\hline $\mathrm{T}_{\mathrm{a}}$ & Atmospheric temperature, in degrees Celsius & ${ }^{\circ} \mathrm{C}$ \\
\hline$\alpha$ & Priestley-Taylor coefficient & dimensionless \\
\hline$\Delta \mathrm{I}$ & $\begin{array}{l}\text { Melt rate of snow and soil pore ice, expressed as an equivalent rate of liquid water } \\
\text { production }\end{array}$ & in/d \\
\hline$\Delta \mathrm{S}$ & Rate of change of water storage in the unsaturated zone above the reference level & in $/ d$ \\
\hline$\Delta \mathrm{S}_{\mathrm{c}}$ & Rate of change of water storage on plant surfaces & in/d \\
\hline
\end{tabular}


SYMBOLS-Continued

\begin{tabular}{lll}
\hline Symbol & Meaning & Dimensions \\
\hline$\Delta \mathrm{t}$ & Duration of a time step & $\mathrm{d}$ \\
$\varepsilon_{\mathrm{a}}, \varepsilon_{\mathrm{s}}$ & Emissivities of the atmosphere and of the forest canopy & $\mathrm{dimensionless}$ \\
$\gamma$ & Thermodynamic psychrometer coefficient & $\mathrm{kPa} / \mathrm{K}$ \\
$\gamma^{*}$ & Apparent psychrometer coefficient & $\mathrm{kPa} / \mathrm{K}$ \\
$\theta$ & Volumetric soil-water content & $\mathrm{dimensionless}$ \\
$\theta_{\mathrm{a}}$ & Atmospheric temperature, in kelvins & $\mathrm{K}$ \\
$\lambda$ & Latent heat of vaporization for water & $\mathrm{J} / \mathrm{g}$ \\
$\rho$ & Free-throughfall coefficient, which is the fraction of precipitation that passes & $\mathrm{dimensionless}$ \\
$\rho_{\mathrm{a}}$ & through the canopy without being intercepted by the foliage or branches & $\mathrm{g} / \mathrm{m}^{3}$ \\
$\rho_{\mathrm{w}}$ & Air density & $\mathrm{g} / \mathrm{m}^{3}$ \\
$\sigma$ & Density of water & $\mathrm{W} /\left[\mathrm{m}^{2} \mathrm{~K}^{4}\right]$ \\
& Stephan-Boltzmann constant & \\
ADDITIONAL ABBREVIATIONS & \\
DPM & Deep Percolation Model & \\
$\mathrm{d}$ & day & \\
HRMU & hydrologic response map unit & \\
$\mathrm{h}$ & hour & \\
$\mathrm{s}$ & second & \\
$\mathrm{K}$ & kelvins & \\
\hline
\end{tabular}




\title{
Estimating Recharge to Ground Water from Precipitation at Naval Submarine Base Bangor and Vicinity, Kitsap County, Washington
}

\author{
By W.R. Bidlake and K.L. Payne
}

\section{ABSTRACT}

An investigation was made to develop a simple technique for estimating recharge to ground water from precipitation for an area of about 85 square miles in the vicinity of Naval Submarine Base Bangor, which is in northern Kitsap County, Washington. The approach taken was to estimate downward drainage below the zone of plant roots as a residual of the near-surface water balance for four water-balance intensive study areas. Downward drainage below the root zone was assumed to be equal to recharge to ground water on an annual basis. The recharge estimates were then used to develop predictive equations for annual recharge based on annual precipitation. Different predictive equations were developed for each group of the soil and landcover types that exhibited a unique recharge response to precipitation, and a map of the soil and land-cover groups for the study was developed from existing digital maps of soil and land-cover types.

Annual recharge computed from the water balance ranged from 11.9 to 16.6 inches among the intensive study areas during the period of the investigation. Annual precipitation ranged from 38.9 to 52.1 inches, and annual surface runoff ranged from 5.7 to 17 inches. Annual evapotranspiration, which included evaporation from the soil surface, evaporation of water that was intercepted by vegetation, and plant transpiration, ranged from 19.6 to 24.2 inches.

There were five unique soil and land-cover groups that were mapped for the overall study area: (1) nonforest vegetation on soils formed in glacial outwash and other alluvium, (2) forest vegetation on soils formed in glacial outwash and other alluvium, (3) forest and nonforest vegetation on soils formed on glacial till or fine-grained sediments, (4) developed or urban lands, and (5) water and wetlands. Annual recharge for water bodies and wetlands was assumed to be 0 . Predicted annual recharge decreases from group 1 to group 4 .

Annual recharge estimated from the predictive equations were subject to some significant uncertainties, including uncertainties caused by errors in the recharge estimates that were used to develop the equations, uncertainties caused by lumping many soil and land-cover types into five groups, with the attendant potential for imperfect lack-of-fit of the predictive equations for any given soil or landcover group, and uncertainties caused by errors in estimates of precipitation throughout the study area.

\section{INTRODUCTION}

Naval Submarine Base Bangor (SUBASE Bangor) is a U.S. Navy installation of about $11 \mathrm{mi}^{2}$ (square miles) that has been in operation since 1944. It is located along Hood Canal in Kitsap County, Wash. (fig. 1). As a result of past activities on SUBASE Bangor, about 10 percent of the base contains sites with contaminated soil and shallow ground water. Several of these sites are currently (2001) in remediation, and others will be in the near future. Contaminants include ordnance chemicals, metals, chlorinated hydrocarbons, petroleum hydrocarbons, pesticides, and polychlorinated biphenyls (PCBs). At the inception of this investigation, the contaminated sites had been studied as individual units, rather than on a larger scale.

The U.S. Navy recognizes that an understanding of the ground-water flow system of SUBASE Bangor and surrounding areas is a prerequisite for understanding how contaminated water could flow from shallow to deep aquifers, and how changes in use of deep ground water could affect contaminant pathways and possibly cause intrusion of seawater in nearshore areas. 


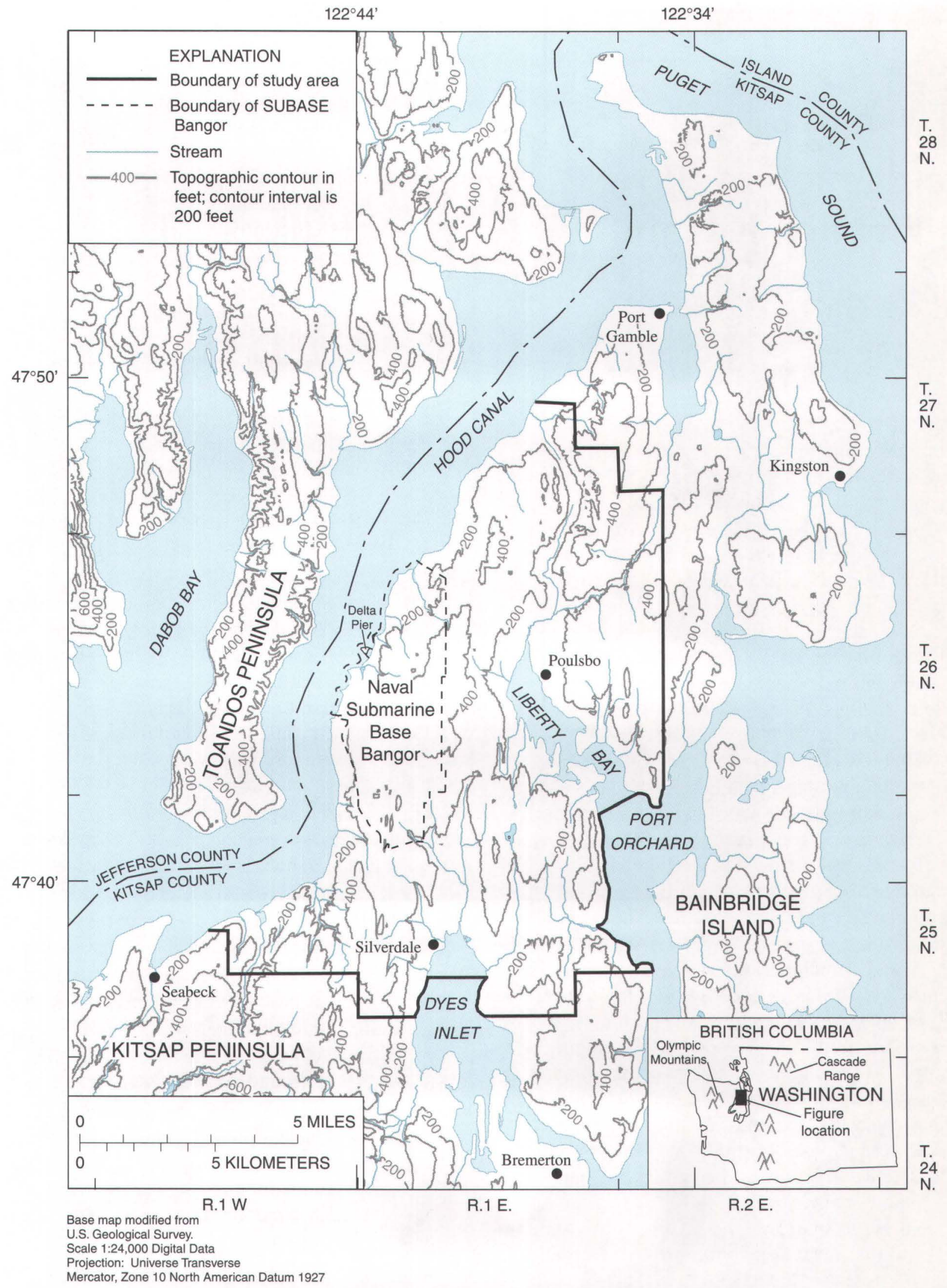

Figure 1. Northern Kitsap Peninsula and the study area. 
In addition, the U.S. Navy also recognizes the need for a thorough understanding of the ambient quality of ground water in the area. As a result, the U.S. Geological Survey (USGS) began an investigation of the hydrology and water quality of SUBASE Bangor and vicinity in 1993, in cooperation with the Department of the Navy, Engineering Field Activity, Northwest Naval Facilities Engineering Command. This report is one of five reports to be published as part of the entire investigation. Topics of the other reports are (1) the estimated ages of ground water, (2) the ambient quality of ground water, (3) hydrogeology of the study area, and (4) the numerically simulated characteristics of the present and future ground-water flow system. The purpose of the investigation that is described by this report was to develop a simple technique for estimating recharge to ground water that could be used in estimating the boundary conditions for numerical simulations of ground-water flow within the study area.

\section{Description of the Study Area}

The study area is on the Kitsap Peninsula of the Puget Sound Lowland in northern Kitsap County (fig. 1). It includes SUBASE Bangor $\left(11 \mathrm{mi}^{2}\right)$ and surrounding land that together cover a total area of about $85 \mathrm{mi}^{2}$. The study area was selected to include hydrologic boundaries that could be used as model boundaries in the numerical simulation of the groundwater flow system to be described in a subsequent report. The peninsula is surrounded by salt water and has a hydrologic setting similar to that of an island. Many coastal areas are steep, with altitudes ranging from sea level to $500 \mathrm{ft}$ (feet) or more above sea level. Inland, slopes are moderate, and many areas are nearly flat. Glacial and interglacial deposits that make up much of the subsurface of the study area are exposed in cliffs along many shorelines. The deposits consist primarily of alternating layers of glacial till, sand and gravel, and silt and clay. Bedrock, which underlies the glacial and interglacial deposits, is estimated to be at about 600 to $1,800 \mathrm{ft}$ below land surface (Jones, 1996).

The study area has a temperate maritime climate. The Kitsap County Ground Water Advisory Committee and others (1991) report that mean annual precipitation ranges from about $30 \mathrm{in} / \mathrm{yr}$ (inches per year) in the northeastern part of the study area to about $60 \mathrm{in} / \mathrm{yr}$ in the southwestern part. Distribution of precipitation is partly controlled by the influence of the nearby
Olympic Mountains to the west. The mountains block or otherwise modify moisture-laden storms that sweep inland from the Pacific Ocean. As is the case for much of the north Pacific Coast of North America, winters are wet and summers are relatively dry. The mean monthly temperature for 1961 to 1990 at Bremerton, 4 miles south of the study area, ranged from $39^{\circ} \mathrm{F}$ (degrees Fahrenheit) in January to $64^{\circ} \mathrm{F}$ in July and August (Owenby and Ezell, 1992). At times, winter temperatures are sufficiently low for a few inches of snow to accumulate. However, snow accumulation usually is not significant.

Approximately 47 percent of the study area is covered by coniferous and deciduous forests and approximately 13 percent by urban and military development. The remaining 40 percent of the study area is covered by nonforest vegetation, which includes agricultural and other vegetative cover.

The population of the study area is concentrated in the two medium-sized towns of Silverdale and Poulsbo (fig. 1), with 1990 populations of 7,660 and 4,848, respectively (U.S. Bureau of the Census, 1992). Outside these towns, the countryside is rural and semirural, and many homes obtain potable water from individual wells instead of public supply systems. From 1970 to 1990 , the study area population increased by a factor of 1.5 to about 39,000 . Continued population growth in the area is likely (Puget Sound Council of Governments, 1988), and increases in demand for water supply will accompany the population growth.

The processes of ground-water recharge include drainage of water from precipitation through an unsaturated soil to the water table, seepage from the bottoms of streams and reservoirs, and introduction of water into ground-water wells. Seepage from septic systems might contribute significantly to ground-water recharge in some developed areas; however, water from precipitation is probably the principal source of recharge for the predominantly sparsely populated lands in the study area.

Knowing the ground-water recharge rate is crucial to understand and manage ground-water systems. In the absence of inflow from adjacent ground-water systems, the sustainable yield of any aquifer is limited to the time-averaged rate of groundwater recharge. When extraction of water from wells and other forms of discharge exceed recharge, groundwater storage is depleted. If water storage is depleted enough, the utility of an aquifer for water production can be compromised. 
The time required for contaminants released near the land surface to reach ground water can depend on the rate of ground-water recharge. Many types of contaminants are carried through unsaturated soil to the water table by water that percolates downward under the force of gravity. The time required for a given water mass to travel through the unsaturated soil to a water table is related to recharge rate by the equation (Gee and others, 1992)

$$
T=\frac{12 L \theta}{R},
$$

where

$T$ is travel time, in years;

$L$ is thickness of the unsaturated soil, in feet;

$\theta$ is volumetric soil-water content, dimensionless; and

$R$ is recharge rate, in inches per year.

Time required for a waterborne contaminant to arrive at a water table (neglecting diffusion, hydrodynamic dispersion, and preferential flow) is inversely proportional to the rate of recharge through the unsaturated zone. Thus, the residence time of contaminants in the unsaturated zone decreases as the rate of recharge increases. Although this retarding only delays the ultimate effects on ground water of contaminant metals and biologically resistant compounds, the longer residence times associated with small recharge rates can afford soilborne organisms the opportunity to degrade some types of contaminants, such as petroleum hydrocarbons, to harmless compounds. Finally, recharge is one of the most important controls on flow dynamics of ground-water systems, and an understanding of recharge is important for understanding and predicting ground-water flow.

Previous investigations of ground water on the northern Kitsap Peninsula have produced several estimates of annual ground-water recharge. In a report prepared by Hart Crowser, Inc. (1988), annual groundwater recharge for an area near Cattail Lake Creek at the north end of SUBASE Bangor (fig. 2) is estimated using the water balance. The Hart Crowser report indicates that average annual precipitation for the area is equivalent to the 40 -year average of annual precipitation at Bremerton (47 in.). Annual evaporative loss is estimated to be 19 in., based on an analysis conducted by Garling and others (1965) for Grapeview, Wash., which is approximately 30 miles south of the Hart Crowser recharge study area.
Average annual surface runoff is estimated by Hart Crowser to be 16 in., based on their analysis of surfacewater records for nearby Dogfish Creek (fig. 2). Finally, Hart Crowser estimates average annual ground-water recharge at their study area to be 12 in.

Becker (1995) estimated ground-water recharge for SUBASE Bangor and surrounding lands that are within a distance of approximately 2 miles from the base. Becker computed recharge as the product of two components he called "effective precipitation" and "infiltration potential." Effective precipitation was computed by multiplying the difference between precipitation measured at Bremerton and evapotranspiration by a spatially variable coefficient that was abstracted from an isohyetal map for the region that was produced by Garling and others (1965). Annual evapotranspiration was estimated to be 21 in. for the study area, based on Garling and others (1965). Infiltration potential was computed by a series of algorithms that incorporated parameters to account for land slope, surficial geology classification, and landcover classification. Becker's computations yielded spatially varying estimates of annual recharge that averaged $16.2 \mathrm{in}$. for undeveloped parts of the study area. Average annual precipitation and surface runoff were reported by Becker to be 47.8 and 10.6 in., respectively.

Vaccaro and others (1998) estimated average annual recharge for the entire Puget Sound Lowland, including the area of this investigation. Their approach involved summarizing several recharge investigations that have been made throughout the lowland. They developed separate equations to predict recharge rates for natural conditions for areas underlain by glacial till or fine-grained sediments and for areas underlain by coarse-grained alluvial deposits. Natural recharge rates were reduced by 50,75 , and 100 percent, respectively, for areas that were classified as residential, built-up, and urban.

\section{Purpose and Scope}

The purpose of this report is to present the methods and results of an investigation to develop a simple technique for estimating recharge to ground water from precipitation for the study area. 


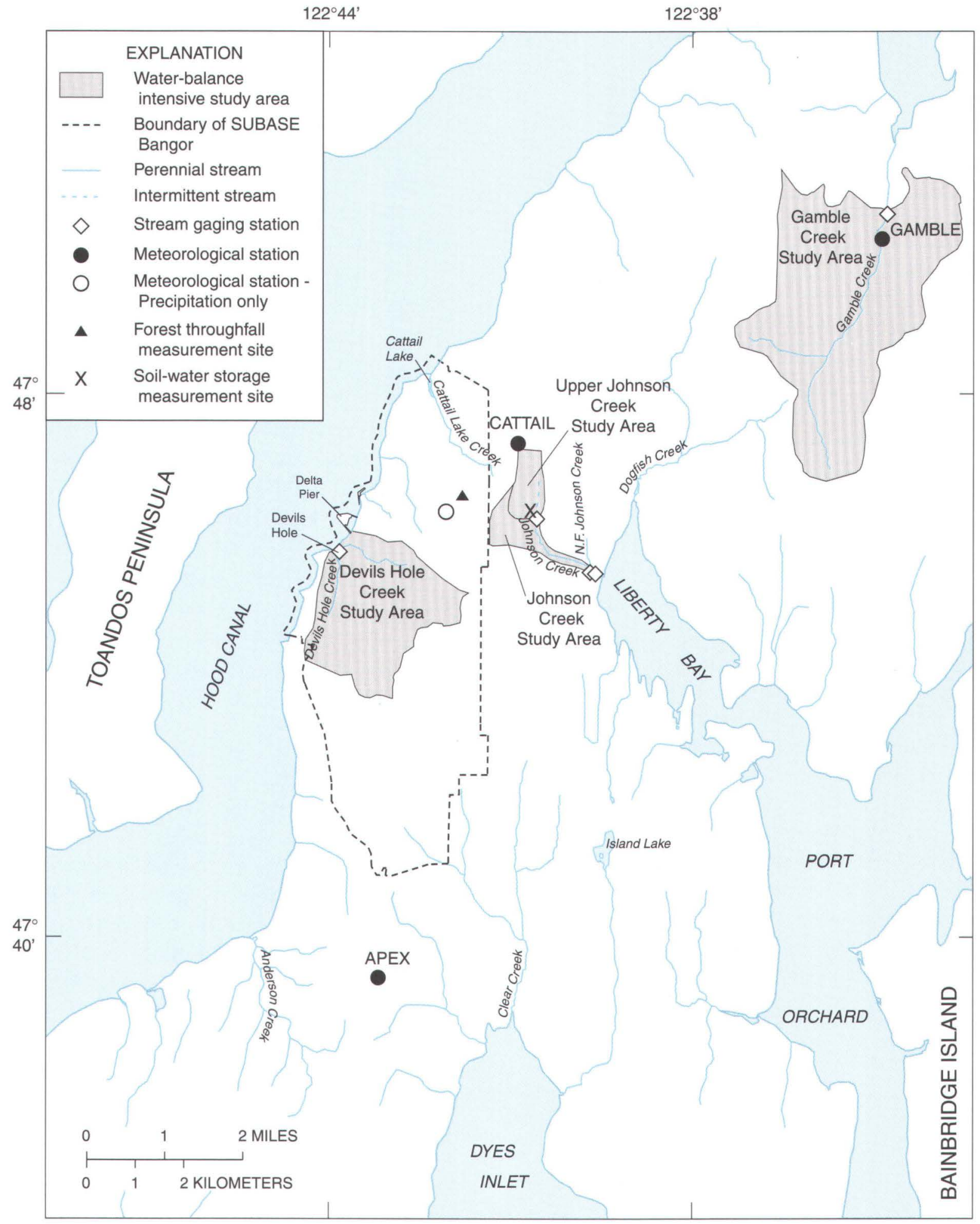

Figure 2. Stream-gaging and meteorological stations, soil water-storage and forest throughfall measurement sites, and the water-balance intensive study areas. 
This report describes (1) how the unsaturated-zone water balance can be used to estimate recharge to ground water from precipitation; (2) field measurements and procedures that were used to estimate water-balance components for selected waterbalance intensive study areas within the overall study area; (3) the application of a water-balance model to estimate downward flow within the unsaturated zone and recharge to ground water; (4) mapping of the study area with respect to soil type, land slope, and landcover type; and (5) the development of a study-area map for estimating average annual recharge from average annual precipitation. The report also discusses some of the significant sources of uncertainty for recharge estimates that are obtained using the recharge map.

\section{Recharge to Ground Water from Precipitation}

Except for extraordinary conditions such as direct injection to a ground-water system, it is generally not possible to measure ground-water recharge directly. Because of this, estimates of groundwater recharge from precipitation are typically computed by analyzing downward flow at a reference level within the unsaturated zone (Gee and others, 1992). Assuming that (1) one-dimensional flow predominates within the unsaturated zone, (2) no sources or sinks for water exist within the unsaturated zone below the reference level, and (3) the average rate of change of water storage within the unsaturated zone below the reference level is 0 , then average recharge is equal to average downward flow at the reference level. Downward flow at the reference level can be inferred from analysis of the unsaturated-zone water balance above the reference level. A unit-area equation for the water balance is (Bauer and Mastin, 1997)

$$
P=E_{s}+E_{t}+E_{i}+R_{o}+\Delta S+\Delta S_{c}-\Delta I+D \quad,
$$

where

$P$ is precipitation rate, in inches per day;

$E_{s}$ is rate of evaporation from the soil surface, in inches per day;

$E_{t}$ is plant transpiration rate, in inches per day;
$E_{i}$ is rate of evaporation from plant surfaces of precipitation that has been intercepted and stored on those surfaces, in inches per day;

$R_{o}$ is direct runoff rate per unit of land area, in inches per day;

$\Delta S$ is rate of change of water storage in the unsaturated zone above the reference level, in inches per day;

$\Delta S_{c}$ is rate of change of water storage on plant surfaces, in inches per day;

$\Delta I$ is melt rate of snow and soil pore ice, expressed as an equivalent rate of liquid water production, in inches per day; and

$D$ is rate of downward flow at the reference level, in inches per day.

The term "evapotranspiration" refers to total evaporative loss, and it includes evaporation from the soil surface, transpiration, and evaporation of intercepted water $\left(E_{s}+E_{t}+E_{i}\right)$.

The most convenient reference level for analysis of the water balance, and the level that was used in this study, is in the near-surface soil below the zone of plant roots. Few water sources or sinks exist within the unsaturated zone below the root zone, and the average rate of change of water storage within the root zone can be measured by any of several field methods. Although the water-balance equation can be used to compute $D$ for any period of time, time-averaged $D$ will only approach time-averaged recharge to ground water if an averaging period is selected for which the average rate of change in water storage in the unsaturated zone below the reference level is 0 . Although this latter rate is usually difficult to assess by direct measurements, it will often approach 0 for 12-month periods for nonirrigated lands where precipitation varies in annual cycles. Increases in unsaturated-zone water storage for such lands during the wet seasons tend to be offset by decreases in storage during the dry seasons.

Although the term "unsaturated zone" strictly refers to any profile of earth materials that is not water saturated, or to any part of such a profile, the term is used in an operational sense in this report to refer to the predominantly unsaturated profile above the uppermost saturated zone that has been identified in the hydrogeologic framework. The profile might include thin or transient water-saturated zones that have not been identified as part of the hydrogeologic framework. 


\section{APPROACH}

The overall design of the investigation was to intensively study downward flow from the root zone for four water-balance intensive study areas (fig. 2) for a 20-month period, and to use what was learned from the intensive studies to develop a simple technique for producing spatially distributed estimates of groundwater recharge for the entire study area. The intensive studies, which used data that were collected beginning in August 1994 and concluding in March 1996, were designed to measure or model all of the important components of the near-surface water balance, and to develop estimates of monthly downward flow from the root zone for major soil and land-cover types. Monthly estimates of downward flow from the root zone and other water-balance components were then used to examine seasonal variations of the water balance, and to identify relations between total downward flow below the root zone and total precipitation for 12-month periods for major soil and land-cover types within the study area. The relational equations were then used to estimate annual recharge to ground water from precipitation for the entire study area.

The intensive studies of downward flow from the root zone were made using the Deep Percolation Model (DPM) that was presented by Bauer and Vaccaro (1987) and later modified by Bauer and Mastin (1997). The DPM is a simplified physical process model that can be used to simulate major components of the nearsurface water balance, including $D$, at a daily time step. The reader is referred to Bauer and Vaccaro (1987) and Bauer and Mastin (1997) for a complete description of the model. Partitioning of $P$ among the components on the right-hand side of equation 2 is in part determined by time-dependent interactions among the components. A daily time step is desirable for simulating the soil-water balance, compared with monthly or longer time steps, when the response and state of two or more interacting components are transitory during the longer time steps. In such cases, the daily time step allows for more accurate representations of the water-balance components.

The two types of data required to operate the DPM are data for characterizing the physical aspects of the soil-plant system to be simulated, including initial conditions, and time-varying data for driving the model to simulate evolution of the water balance from the initial conditions. The characterization data include soil available water capacity and specific yield within the root zone, vertical hydraulic conductivity of subsoil materials that lie beneath the root zone, land slope, vegetation type, rooting depth, and initial status of soilmoisture storage. Data to drive the model typically include time series of daily precipitation, daily maximum and minimum air temperature, daily total solar radiation, and daily direct surface runoff. The DPM is structured to simulate the plant canopy waterbalance components $E_{i}$ and $\Delta S_{c}$, or alternatively, to accept results from independent measurements or calculations of interception loss. For the latter case, the model accepts the fraction of daily precipitation that is not stored within or evaporated from the plant canopy with which it computes a reduced, effective precipitation for solution of equation 2 (Bauer and Mastin, 1997). For this investigation, the canopy water balance for forested areas, which can exhibit relatively large interception losses, was computed independently from the DPM using a simple canopy water-balance analysis, which is described subsequently in this report, and results from the analysis were supplied for the DPM simulations. For areas of nonforest vegetation, for which interception loss is relatively small, simulations were conducted assuming that evapotranspiration rates from dry foliage were the same as evapotranspiration rates from wetted foliage.

Intensive studies of downward flow from the root zone were made with the DPM for the four waterbalance intensive study areas (table 1, fig. 2). Study area physical characteristics of most interest for implementation of the DPM vary principally with soil type, land slope, and land cover. Each intensive study area is a complex mosaic of different soil types, land slopes, and land-cover types. Existing digital geographic data sets for soils, land slope, and land cover were used to develop estimates of the physical characteristics needed to implement the DPM for each intensive study area. The Upper Johnson Creek waterbalance intensive study area is in terrain that is almost flat with soils derived exclusively from glacial till. The flatness of the terrain made precise definition of drainage basin boundaries extremely difficult and error prone, and the Upper Johnson Creek study area depicted on figure 2 likely includes the drainage subbasin of Upper Johnson Creek, as well as parts of neighboring basins. A contributing area of $0.15 \mathrm{mi}^{2}$ was used with streamflow data from station 12070040 to compute direct runoff. Eighty percent of the intensive study area is covered with coniferous forests and the remaining 20 percent of the land area is covered by nonforest upland vegetation and a small housing tract. 
Table 1. Water-balance intensive study areas

\begin{tabular}{llcc}
\hline $\begin{array}{l}\text { Water-balance } \\
\text { intensive } \\
\text { study area }\end{array}$ & Description & $\begin{array}{l}\text { Area } \\
\text { (square } \\
\text { miles) }\end{array}$ & $\begin{array}{l}\text { Stream-gaging } \\
\text { station used for } \\
\text { computing runoff }\end{array}$ \\
\hline Upper Johnson Creek & $\begin{array}{l}\text { In the vicinity of an intermittent reach of } \\
\text { Johnson Creek upstream of the confluence } \\
\text { with the North Fork of Johnson Creek }\end{array}$ & 0.33 & 12070040 \\
Johnson Creek & $\begin{array}{l}\text { In the vicinity of Johnson Creek upstream } \\
\text { of the confluence with the North Fork of } \\
\text { Johnson Creek }\end{array}$ & 0.71 & 112070045, \\
Gamble Creek & $\begin{array}{l}\text { Subbasin for Gamble Creek above a point } \\
\text { approximately 1 mile upstream of the mouth } \\
\text { of Port Gamble Inlet }\end{array}$ & 5.97 & 12070050 \\
Basin drains to Hood Canal from Naval & & 12069651 \\
Devils Hole Creek & Submarine Base Bangor & 2.61 & 12069600 \\
\hline
\end{tabular}

${ }^{1}$ Flow of Johnson Creek upstream of the confluence with the North Fork of Johnson Creek was computed by subtracting gaged flow of the North Fork at the confluence (station 12070045) from gaged flow on the main stem immediately below the confluence (station 12070050).

The Johnson Creek water-balance intensive study area includes the upper Johnson Creek study area and areas of nearly flat terrain near the crest of the Kitsap Peninsula, as well as an area of steeper slopes that is close to Liberty Bay (fig. 2). The flatness of the terrain made precise definition of drainage basin boundaries extremely difficult and error prone, and the Johnson Creek intensive study area that is depicted on figure 2 likely includes the drainage subbasin of Johnson Creek upstream of the confluence with the North Fork of Johnson Creek, as well as parts of neighboring basins. Direct runoff was computed using gaged streamflow at station 12070050 minus that at station 12070045, and using a contributing area of $0.53 \mathrm{mi}^{2}$. Ninety-three percent of the land area of the intensive study area is covered by soils that were formed on glacial till, and the remainder of the land area is covered with soils of developed or urban areas, which are principally modified glacial-till soils, or by soils that formed in wetlands. Seventy-two percent of the Johnson Creek water-balance intensive study area is covered by coniferous and mixed coniferous and deciduous forests, and 21 percent is covered by nonforest upland vegetation.

The Gamble Creek water-balance intensive study area comprises both gently and steeply sloping inland terrains within the Gamble Creek Basin. Much of the gently sloping land is occupied by small farms. Sixtyeight percent of the land area of the intensive study area is covered by soils that were formed on glacial till, 28 percent is covered by soils that formed in alluvium, and the remaining land area is covered by soils of developed or urban areas or by wetland soils. Coniferous and mixed deciduous and coniferous forests occupy 53 percent of the land area of the Gamble Creek intensive study area, and nonforest upland vegetation, including agricultural and wildland vegetation, occupy 43 percent of the land area.

The Devils Hole Creek water-balance intensive study area occupies the Devils Hole Creek Basin on the western slope of the Kitsap Peninsula (fig. 2), and it contains many installations of SUBASE Bangor. Fiftyfour percent of the land area is covered by soils that were formed on glacial till, 21 percent of the land area is covered by soils formed in alluvium, and the remaining land area of the intensive study area is covered by soils of developed or urban areas, by open water, or by wetland soils. Coniferous and mixed deciduous and coniferous forests occupy 53 percent of the Devils Hole Creek intensive study area. Nonforest upland vegetation, including some of the large fields that surround SUBASE Bangor installations, occupies 22 percent of the land area. 
Field Measurements and Computations to Support Implementation of the DPM

A program of field measurement to supply data for operating the DPM for the water-balance intensive study areas began during summer 1994, and it concluded in April 1996. Stream discharge ( $Q$, in cubic feet per second) was monitored at gaging stations that were located at the downstream end of each of the water-balance intensive study areas (fig. 2).

Daily mean $Q$ was computed by averaging a daily time series of instantaneous $Q$. Instantaneous $Q$ was computed from measurements of stream stage made within a stilling well, and from a mathematical relation, called a rating curve, that related $Q$ to stream stage. The rating curve was calibrated for each gaging station using concurrent measurements of $Q$ and stage. Discharge used for the calibrations was measured with either a portable current meter or by timing volumetric outflow into a container with a stopwatch. Stream discharge data collected at the gaging stations listed in table 1 are published in Wiggins and others (1996 and 1997).

The DPM computes $R_{o}$ using an expression equivalent to $R_{o}=1.037 \times 10^{6}\left(Q-Q_{b}\right) / A_{Q}$, where $Q_{b}$ is base flow discharge, the flow in a stream due to the discharge of ground water to the stream, in cubic feet per second $\left(\mathrm{ft}^{3} / \mathrm{s}\right)$; and $A_{Q}$ is area of the drainage basin that contributes to direct runoff at a gaging station, in square feet. Base flow was estimated by inspection of the time series of daily flow rather than on the basis of trend-based mathematical models (Pilgrim and Cordery, 1992) because, in till-mantled areas, water that ponds on top of the till and within the soil profile can persist for days or weeks, and the contribution of the ponded water to streamflow is difficult to distinguish from the contribution from ground water (Vaccaro and others, 1998). For Gamble and Devils Hole Creeks, $Q_{b}$ during November through April was assumed to be equal to approximately 75 percent of $Q$ for selected low-flow periods, and $Q_{b}$ was assumed to equal $Q$ of selected low-flows during the remainder of the year. Estimates of $Q$ for Johnson Creek upstream of the confluence with the North Fork of Johnson Creek, which were obtained by subtracting gaged flows of the North Fork from gaged flows of the main stem, were at times erratic because of the accumulation of measurement errors for the two gaged reaches. Base flow of Johnson Creek at the confluence with the North Fork of Johnson Creek was assumed to be the lesser of $0.7 \mathrm{ft}^{3} / \mathrm{s}$ or total computed streamflow. Upper Johnson Creek was an intermittent stream and $Q_{b}$ was assumed to be 0 (fig. 3).

Knowledge of soil-water storage is useful for specifying initial conditions for simulations made with the DPM and for assessing whether or not the simulations accurately track seasonal variations of water storage. Soil-water storage, in inches, is equal to the product of volumetric soil-water content (dimensionless) and soil thickness, in inches. Soilwater storage was computed using measurements of soil thickness and volumetric soil-water content made by time domain reflectometry (Topp and others, 1980). Four soil-water storage measurement stations were monitored at the soil-water storage measurement site in the Upper Johnson Creek intensive study area (fig. 2). The four stations were within a radius of approximately 300 feet of the center of the site. Measurements of soilwater content were made periodically at intervals that were normally about 30 days.

Operation of the DPM requires the meteorological inputs of daily solar radiation, daily maximum and minimum air temperature, and daily precipitation. Three temporary meteorological stations were installed within the study area to collect meteorological data needed to operate the model. The meteorological stations were named Apex (USGS station number 473930122432000), Cattail (USGS station number 474525122410000), and Gamble (USGS station number 474740122350000). Location of each station is shown on figure 2. Each station monitored solar radiation, air temperature, precipitation, wind speed, and relative humidity at 15-minute intervals. Graphical summaries of time series for solar radiation, air temperature, and precipitation shown for meteorological station Cattail (fig. 4) are representative of the time series for meteorological stations Apex and Gamble. 


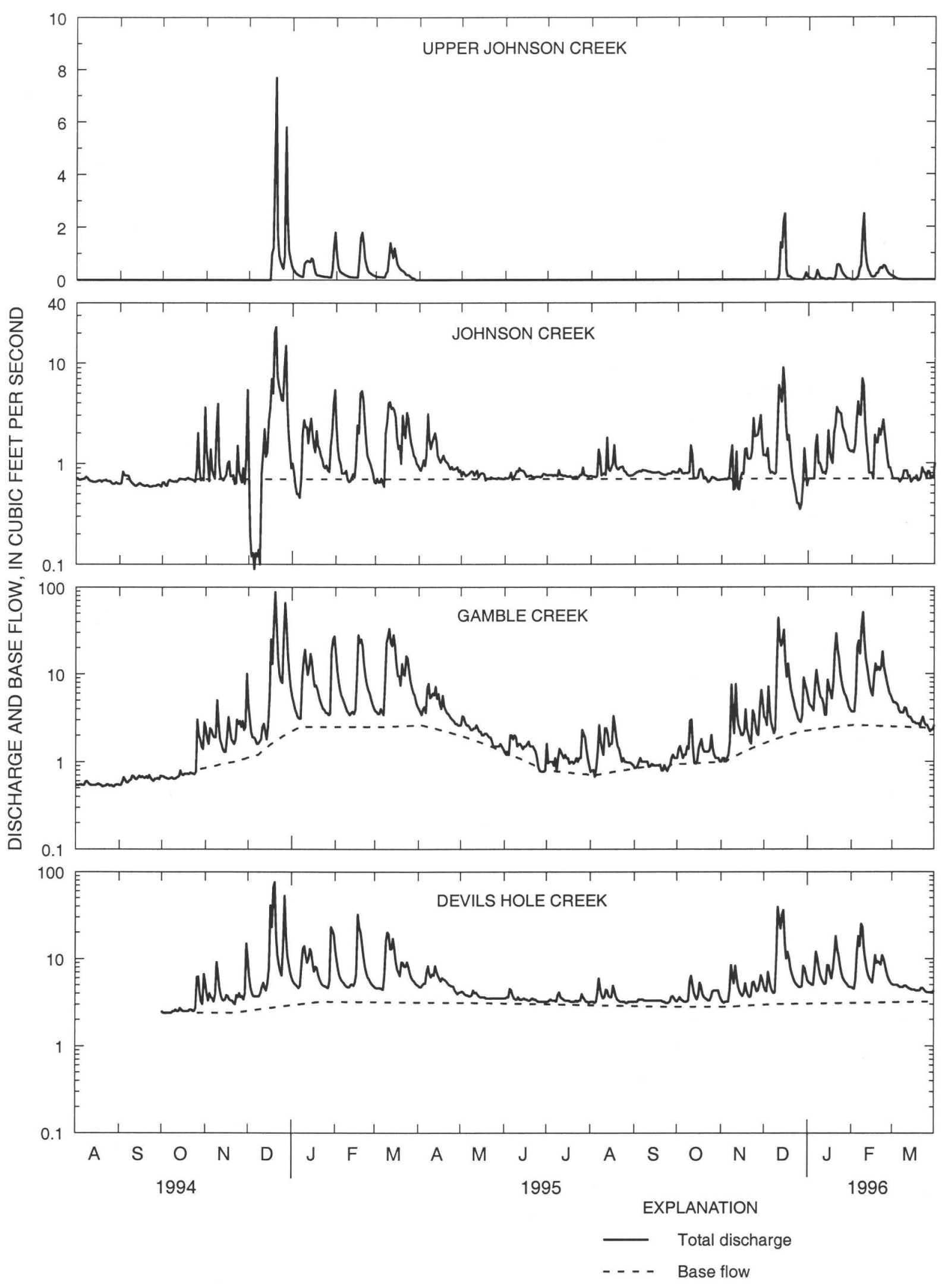

Figure 3. Total stream discharge and base flow for streams used for estimating direct runoff from the water-balance intensive study areas. 

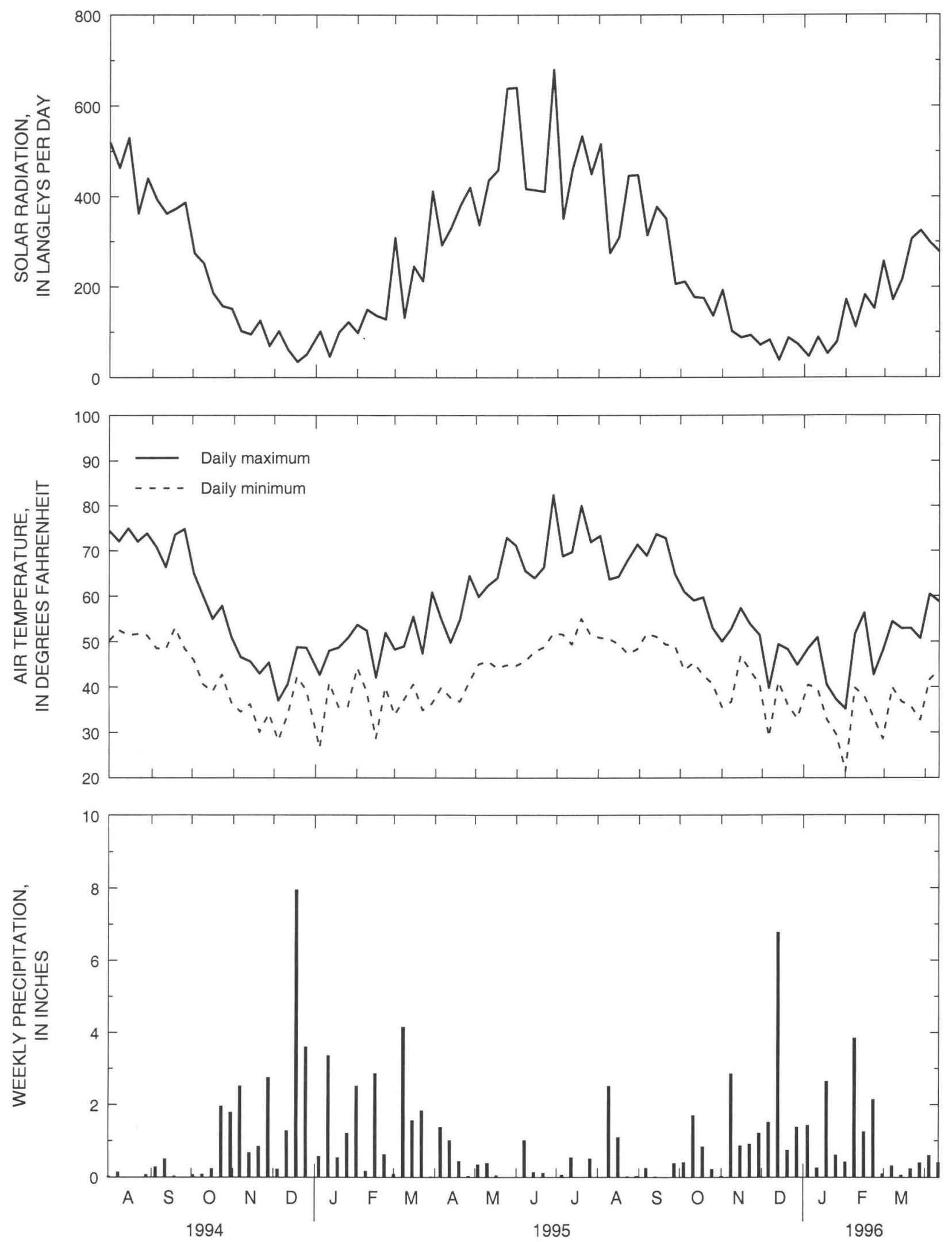

Figure 4. Seven-day average of daily solar radiation and daily maximum and minimum air temperature, and 7-day total of precipitation as measured at the Cattail meteorological station (station number 474525122410000). 


\section{Procedures for Measuring and Predicting Interception Loss}

Evaporation of intercepted precipitation from wet plant surfaces $\left(E_{i}\right)$, which is referred to as "interception loss" in some hydrologic literature, can be an important component of the water balance of forested areas. Forests are aerodynamically rough, and this promotes efficient turbulent exchange between forest canopies and the bulk atmosphere. As a result, evaporation of intercepted water from forest canopies is rapid compared with evaporation of intercepted water from short, aerodynamically smooth vegetation. A large portion of the study area is forested with conifers, yet little is known about the magnitude or seasonal timing of interception losses from forests in the Pacific Northwest. One study of interception loss made by Bauer and Mastin (1997) for a conifer stand in the Puget Sound Lowland indicated interception loss accounted for about 50 percent of precipitation during a 13-month period. Because of the potential importance of interception loss for the water balance, a concerted effort was made in this investigation to estimate that water-balance component. The effort involved both measurement of interception loss for a stand of conifers within the study area and development of a simple interception-loss prediction procedure. The investigated stand of approximately 80-year-old Douglas-fir was typical of many of the second-growth forests on the Kitsap Peninsula. Projected leaf area index (LAI) of the stand was approximately 10 .

An examination of interception loss for a forest can begin with a simplified equation of the water balance of the forest canopy:

$$
P=\rho P+D_{r}+E_{i}+\Delta S_{c},
$$

where

$\rho$ is the free-throughfall coefficient, which is the fraction of precipitation that passes through the canopy without being intercepted by the foliage or branches, dimensionless;

$D_{r}$ is meteoric water that drips from canopy surfaces to the forest floor, in inches per day; and other terms are as previously defined.

The sum of free throughfall and drip water $\left(\rho P+D_{r}\right)$ is referred to simply as throughfall in the remainder of this report. Flow of meteoric water down tree stems to the forest floor, which is termed "stemflow," is not accounted for by equation 3 . Errors caused by the neglect of stemflow in coniferous forests are likely negligible (Rothacher, 1963; Fritschen and others, 1977). An alternative expression for $\Delta S_{c}$ that can be used in evaluation of equation 3 over a discrete time step is:

$$
\Delta S_{c}=\frac{S_{c}^{j}-S_{c}^{j-1}}{\Delta t},
$$

where

$j$ is a time-step index where $j$ represents the current time step and $j-1$ represents the most recent time step, dimensionless;

$S_{c}$ is the amount of water stored by the canopy, in inches; and

$\Delta t$ is duration of a time step, in days.

A procedure for predicting the water-balance components on the right-hand side of equation 3 was developed that is similar to a procedure advanced by Rutter and others (1971). The procedure employs a simple accounting of each water-balance component, and the accounting is advanced in time from specified initial conditions using discrete time steps. The meteorological data of average flux density of global solar radiation and air temperature, and total precipitation for a time step are used to advance the water-balance accounting in time. The procedure computes each water-balance component for each time step using the following sequence of steps:

1. Compute potential evaporation rate $\left(E_{p}\right)$, the evaporation rate from a wet surface under prevailing meteorological conditions, in inches per day. The procedure for computing $E_{p}$ is described later in this report;

2. Compute the amount of water that is intercepted by the canopy during the current time step $j$, $\Delta t(1-\rho) P$

3. If $\Delta t(1-\rho) P+S_{c}^{j-1}>S_{c m}$, where $S_{c m}$ is the water-storage capacity of the canopy, compute $D_{r}$ as $D_{r}=(1-\rho) P-\left(S_{c m}-S_{c}^{j-1}\right) / \Delta t$; otherwise, set $D_{r}=0$;

4. Set $S_{c}^{j}$ equal to the lesser of $S_{c m}$ and $\Delta t(1-\rho) P+S_{c}^{j-1}$;

5. If $S_{c}^{j}>0$, set $E_{i}$ equal to the lesser of $E_{p}$ and $S_{c}^{j} / \Delta t$; otherwise, set $E_{i}=0$;

6. Set $S_{c}^{j}$ equal to $S_{c}^{j}$ from step 4 minus $\Delta t E_{i}$; and

7. Compute total throughfall at the forest floor for the time step as the quantity $\Delta t\left(\rho P+D_{r}\right)$. 
Potential evaporation rate is computed using a form of the Penman equation that is given by Campbell (1977, equation 10.23). The equation for $E_{p}$ can be written

$$
\begin{aligned}
E_{p} & =\frac{C}{\rho_{w} \lambda} \frac{s}{s+\gamma^{*}}\left[S_{t}\left(1-a_{s}\right)+\sigma \theta_{a}^{4}\left(\varepsilon_{a}-\varepsilon_{s}\right)\right. \\
& \left.+\rho_{a} c_{p}\left(e_{s}-e_{a}\right) /\left(s r_{e}\right)\right]
\end{aligned}
$$

where

$C$ is a factor $\left(3.402 \times 10^{6}\right)$ to convert from meters per second to inches per day;

$\rho_{w}$ is density of water, which is assumed to be $1.0 \times 10^{6}$ grams per cubic meter;

$\lambda$ is latent heat of vaporization for water, which is equal to 2,450 joules per gram at a temperature of 293 kelvin (20 degrees Celsius);

$s$ is slope of the relation between the vapor pressure of water-saturated air and temperature, in kilopascals per kelvin;

$\gamma^{*}$ is the apparent psychrometer coefficient, in kilopascals per kelvin;

$S_{t}$ is flux density of incoming short-wave radiation, in watts per square meter;

$a_{s}$ is reflectivity of the forest canopy to shortwave radiation, dimensionless;

$\sigma$ is the Stephan-Boltzmann constant, which is equal to $5.67 \times 10^{-8}$ watts per square meter per kelvin raised to the fourth power;

$\theta_{a}$ is atmospheric temperature, in kelvins, which is computed from $\theta_{a}=T_{a}+273$, where $T_{a}$ is atmospheric temperature, in degrees Celsius;

$\varepsilon_{a}, \varepsilon_{s}$ are emissivity of the atmosphere and of the forest canopy, dimensionless;

$\rho_{a}$ is air density, which is assumed to equal 1,200 grams per cubic meter;

$c_{p}$ is specific heat of air at constant pressure, which is assumed to equal 1.0 joules per gram per kelvin;

$e_{s}$ is atmospheric water-vapor pressure at saturation, in kilopascals;

$e_{a}$ is atmospheric water-vapor pressure, in kilopascals; and $r_{e}$ is a parallel equivalent resistance to exchange of sensible heat and long-wave radiative energy between the atmosphere and the forest canopy, in seconds per meter.

The apparent psychrometer coefficient $\gamma^{*}$ is given by the equation

$$
\gamma^{*}=\gamma \frac{r_{a}}{r_{e}}
$$

where

$\gamma$ is the thermodynamic psychrometer coefficient, which is equal to 0.066 kilopascals per kelvin at a temperature of $293 \mathrm{~K}$ and atmospheric pressure of 101 kilopascals; and

$r_{a}$ is aerodynamic resistance to transport of scalar quantities, such as sensible heat and water vapor, between the forest canopy and the atmosphere, in seconds per meter.

An equation for $r_{e}$ is

$$
r_{e}=\frac{r_{a} r_{r}}{r_{a}+r_{r}}
$$

where

$r_{r}$ is termed a "radiative resistance" (Campbell, 1977 , p. 89), and is a coefficient that accounts for response of the canopy longwave radiation balance to the canopy-toatmosphere temperature difference, in seconds per meter.

An equation for $r_{r}$ is

$$
r_{r}=\rho_{a} c_{p} / 4 \varepsilon_{s} \sigma \theta_{a}^{3}
$$

Equation 5 is a combination equation that involves both energy-balance and aerodynamic transport components, much like the original Penman equation (Penman, 1956) and the derivative PenmanMonteith equation (Monteith, 1965), and it can be used to estimate $E_{p}$ when measurements of net radiation for the forest canopy are not available. Of the many components of equation 5 and the auxiliary equations 6 through 8 , the components $C, \rho_{w}, \lambda, a_{s}, \sigma, \varepsilon_{s}, \rho_{a}$, $c_{p}, \gamma$, and $r_{r}$ are constants, or can be computed with sufficient accuracy if one has rough estimates of $\theta_{a}$ and total atmospheric pressure, or can be estimated based on characteristics of most natural surfaces. 
For example, Campbell (1977, p. 54 and 49) gives a value for $a_{s}$ of 0.16 for coniferous forest and notes that $\varepsilon_{s}$ for natural surfaces ranges from 0.9 to 0.98 . A value for $\varepsilon_{s}$ of 0.97 was adopted for this report. The value of $s$ varies strongly with temperature and can be computed with the equation

$$
s=\frac{5,307 e_{s}}{\theta_{a}^{2}},
$$

where $e_{s}$ can be computed from $T_{a}$ using the equation given by Lowe (1977).

The remaining variables that must be assigned values before $E_{p}$ can be computed are $S_{t}, \theta_{a}, \varepsilon_{a}, e_{s}, e_{a}$, and $r_{a}$. For this investigation, all of these variables, except $r_{a}$, were estimated based on measurements that were made at meteorological station Cattail, which was in a pasture approximately $5,000 \mathrm{ft}$ northeast from the forest stand. Values for $S_{t}$ and $T_{a}$ were taken from the hourly record of that meteorological station, $\theta_{a}$ was computed from $T_{a}$ as was described previously, and daily average $\varepsilon_{a}$ was estimated from daily average $S_{t}$ and $e_{a}$ using the procedure given by Campbell (1985, p. 134 to 136). Daily average $e_{a}$ was computed by assuming the dewpoint is constant for each day and equal to daily minimum $T_{a}$. Finally, aerodynamic theory indicates that $r_{a}$ tends to be inversely proportional to wind speed, and is also controlled by the aerodynamic characteristics of the forest canopy and by atmospheric stability; however, determination of $r_{a}$ for a tall forest canopy using aerodynamic theory is a difficult and error-prone procedure that requires measurements of wind speed above the canopy. For these reasons, the approach taken in this investigation was to set $r_{a}$ equal to a constant value that was determined as part of the parameterization for the interception-loss prediction procedure described below.

Measured interception loss from the investigated stand was determined as the difference between total precipitation measured in a nearby clearing and throughfall measured beneath the forest canopy. Initially, precipitation measured at meteorological station Cattail was used in determination of interception loss. Precipitation data collected with a tipping-bucket rain gage at the meteorological station were used from January to October 1995. Beginning in October 1995 and continuing until March 1996, precipitation was measured in a clearing that was about
$2,000 \mathrm{ft}$ southwest from the stand. Precipitation at the latter site was collected with an 18-foot-long trough that was 2-in. wide, and that drained to a tipping-bucket rain gage that was calibrated for the collection area of the trough. Switching the precipitation-measurement site and method probably improved the reliability of data because: (1) precipitation at the new site that was closer to the forest stand where throughfall was measured was likely more representative of precipitation that fell on the stand; and (2) the trough was of the same design as the troughs that were used to collect throughfall, and it had similar precipitationcatch characteristics as the troughs that were used to collect throughfall.

Throughfall was measured beneath the forest canopy using an array of three troughs. Troughs, rather than simple rain gages, were used because free throughfall and drip under a plant canopy vary spatially, and the troughs present a relatively large and widely distributed surface to collect spatially averaged amounts of throughfall. One trough each was placed under relatively dense, moderately dense, and relatively sparse parts of the forest canopy. Drainage from each trough was measured with a separate tipping-bucket rain gage, and the average of throughfall from the three trough-and-gage assemblies was assumed to represent the stand-average throughfall. When one of the assemblies malfunctioned, throughfall for that assembly was estimated from a correlation with throughfall measured with one of the remaining assemblies. When two or more assemblies failed, no attempt was made to estimate stand-average throughfall or interception loss. Occasional malfunctions that affected one or more trough-and-gage assemblies were caused by breaking of signal wires in the forest by falling snags, plugging of the tipping-bucket rain gages by litter from the canopy, or by accumulation of snow and ice in the troughs and gages.

The interception-loss prediction procedure was calibrated for the stand by estimating $S_{c m}$ and $\rho$ using time series of precipitation and stand-average throughfall for all odd-numbered storms or a subset of odd-numbered storms during January 1995 to March 1996, and by then adjusting $r_{a}$ to obtain reasonable agreement between cumulative measured and predicted interception loss for all measured storms during that period. The use of odd-numbered storms for estimating $S_{c m}$ and $\rho$ and the subsequent use of all storms to estimate $r_{a}$ was intended to maintain a degree of statistical independence between the estimates for $S_{c m}$ and $\rho$ and the estimate for $r_{a}$. 
The canopy parameter $S_{c m}$ was evaluated following the procedure outlined by Rutter and others (1971) in which a line with a slope of unity is fitted as the upper envelope to points in a plot of total-storm throughfall against total-storm precipitation (fig. 5). The intercept of the line is equal in magnitude and opposite in sign to $S_{c m}$. The logic of this procedure for estimating $S_{c m}$ is that once an initially dry canopy is saturated, throughfall will equal precipitation if evaporation is negligible, hence the line with a slope of unity. The upper limit of points on the plot (fig. 5) represents storms with the smallest total evaporation, which typically are brief storms with relatively small total precipitation. The average value of $S_{c m}$ that was obtained in the above manner was $0.035 \mathrm{in}$. This value can be compared with the value of 0.03 in. obtained by Gash and Morton (1978) for a stand of Scots pine in Great Britain and a value of 0.04 in. obtained by Rutter and others (1971) for a stand of Corsican pine in Great Britain.

The parameter $\rho$ was estimated by analysis of the 15-minute time series of individual odd-numbered storms. Water falling from the canopy from the beginning of a storm and until the time the canopy is saturated and begins to drip is exclusively free throughfall (assuming the canopy does not begin to drip until it is saturated). A value for $\rho$ can be computed from a time series as the ratio of cumulative throughfall to cumulative precipitation immediately before the canopy becomes saturated. Neglecting evaporation, the canopy will become saturated when the storm total precipitation minus throughfall is equal to or greater than $S_{c m}$. Because analysis for $\rho$ is sensitive not only to the total amount of precipitation from a storm but also the timing of precipitation, only odd-numbered storms that occurred while precipitation was measured within $2,000 \mathrm{ft}$ of the stand were used for the analysis (October 1995 to March 1996). To reduce the amount of detailed analysis required and yet to sample the complete time series of odd-numbered storms, every third of those storms was used to compute a value for $\rho$. The cumulative time series of the relevant 15-minute water fluxes for the five storms that were analyzed are presented in figure 6 . The values of $\rho$ that were obtained from the time series ranged from 0.28 to 0.53 and averaged 0.43 . This average value can be compared with $\rho$ that has been reported for stands of Scots pine (0.32; Gash and Morton, 1978) and stands of Corsican pine and Douglas-fir (0.25 and 0.09; Rutter and others, 1975), all in Great Britain.

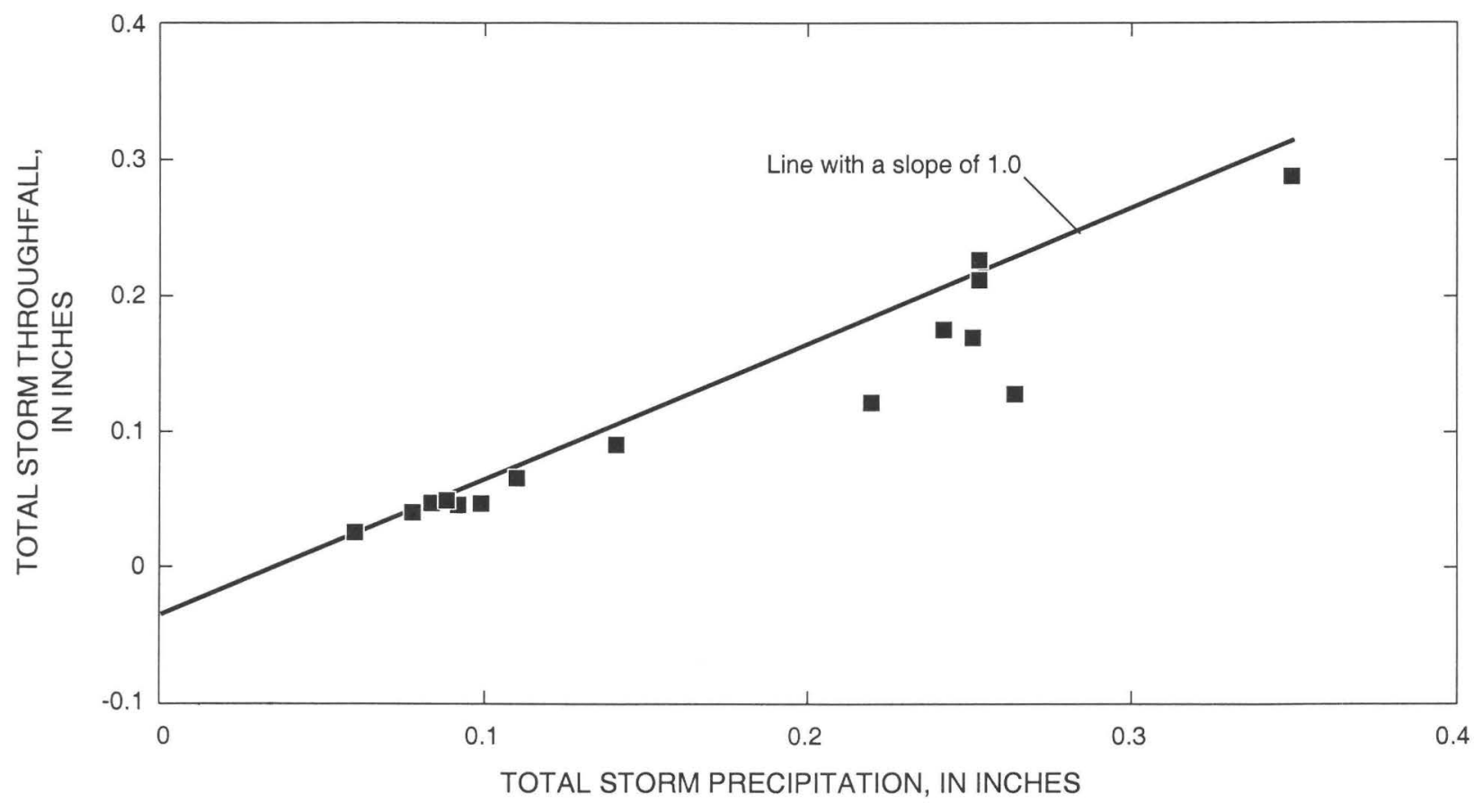

Figure 5. Total storm throughfall and total storm precipitation for odd-numbered storms with total storm precipitation of less than 0.4 inches during January 1, 1995 to March 31, 1996. 

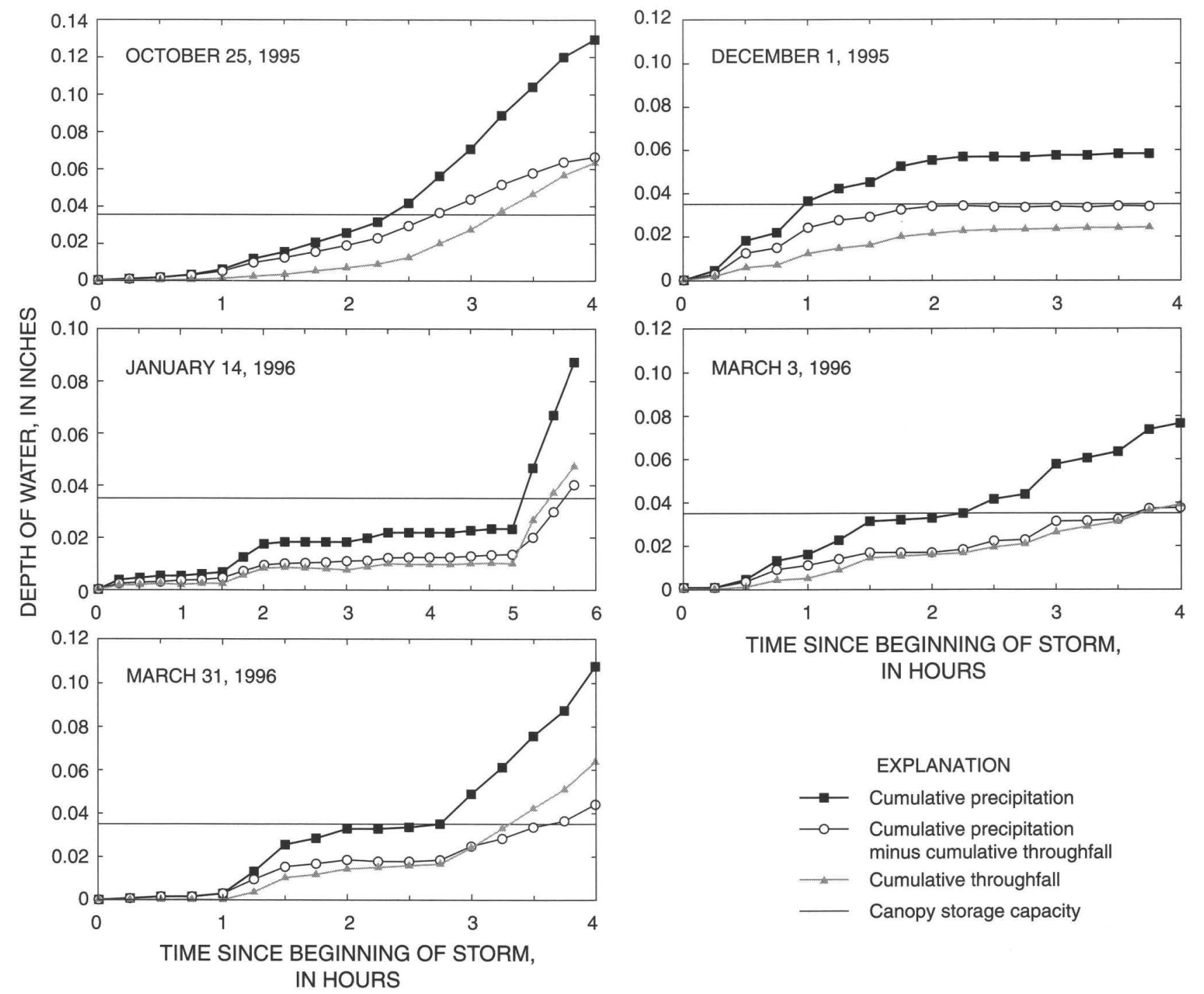
IN HOURS

\section{EXPLANATION}

$\rightarrow$ Cumulative precipitation

- - Cumulative precipitation minus cumulative throughfall

$\rightarrow$ Cumulative throughfall

Canopy storage capacity

Figure 6. Cumulative precipitation, cumulative precipitation minus cumulative throughfall, and cumulative throughfall during the initial hours of five different storms.

The approach taken to estimate $r_{a}$ was to program the interception-loss prediction procedure on a computer; to select an initial estimate for the variable based on published values from similar investigations, which are cited below; to run the program for all measured storms using an hourly time step; and then to vary $r_{a}$ to obtain the best possible agreement between cumulative measured interception loss and cumulative interception loss that was predicted by the procedure (fig. 7). The optimal value for $r_{a}$ that was obtained in this manner was $10 \mathrm{~s} / \mathrm{m}$ (rounded to the nearest $5 \mathrm{~s} / \mathrm{m}$ ), which was within the range of values for $r_{a}$ that have been used for several other investigations of evaporation from coniferous forests (McNaughton and Black, 1973, approximately 5 to 45 s/m; Stewart, 1977, $6 \mathrm{~s} / \mathrm{m}$; Rhia and Campbell, 1985, $10 \mathrm{~s} / \mathrm{m}$; and Running and Coughlan, 1988, $5 \mathrm{~s} / \mathrm{m}$ ). Both measured and predicted interception loss accounted for about 20 percent of the measured precipitation. 


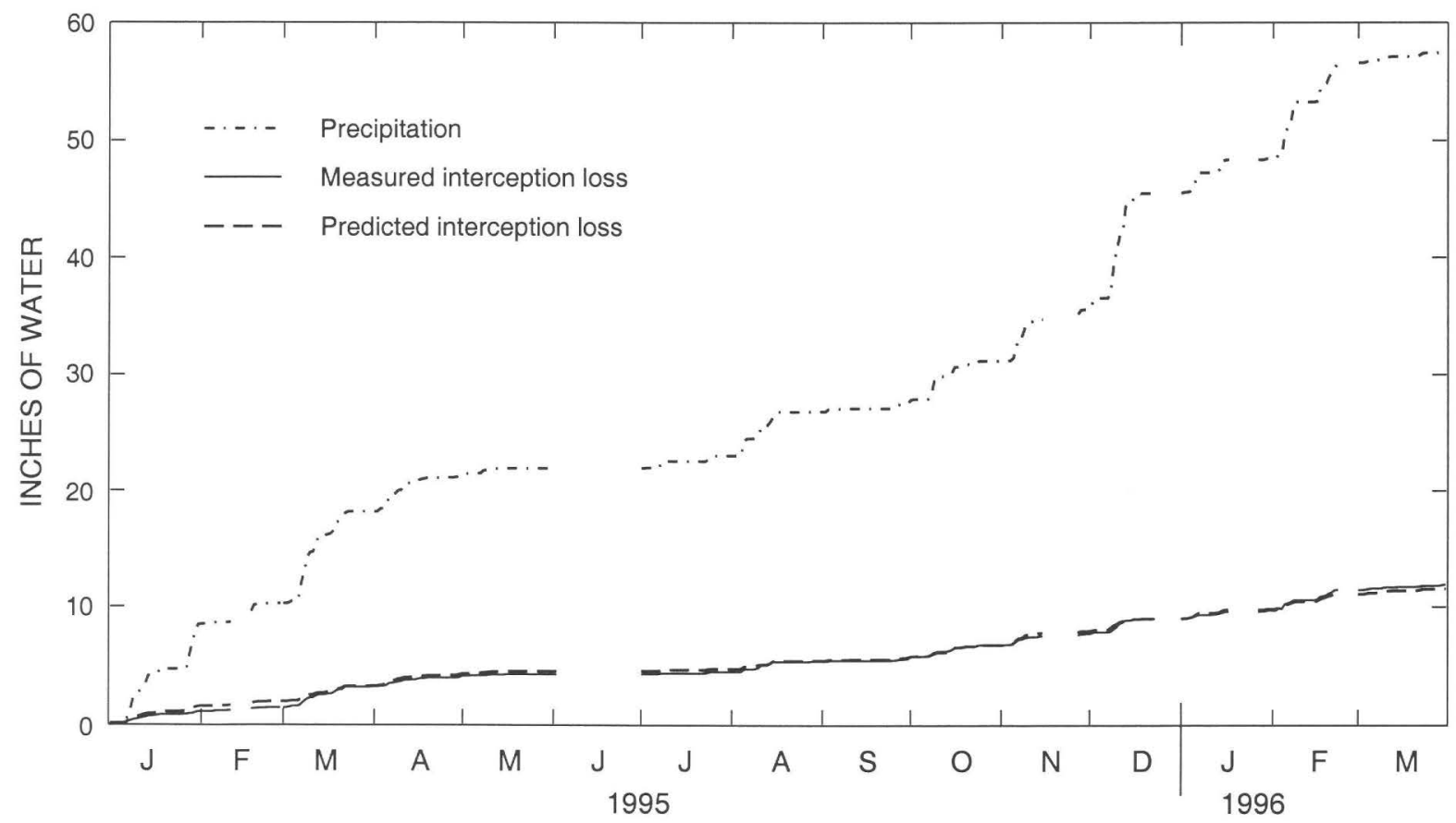

Figure 7. Cumulative precipitation, cumulative measured interception loss and cumulative predicted interception loss for January 1, 1995 to March 31, 1996. Gaps in the data presented are for periods for which data for computing interception loss were missing or insufficient.

The interception-loss prediction procedure was used to predict a daily time series of interception loss at each of the three temporary meteorological stations, assuming that an equivalent forest stand was present at each station. The three time series of predicted interception loss were used to compute time series of reduced, effective precipitation that were then used for the DPM simulations of the soil-water balance of forested areas as was described previously.

\section{Assembling Data Bases for DPM Simulations}

Digital geographic data used to support implementation of the DPM were obtained for soils, land slope, and land cover. The geographic data were used as a basis for making spatially based assignments to DPM variables that characterize soil and vegetation physical properties that are important for partitioning the water balance. The original (source) geographic data sets for soils and land cover were reclassified using simplified schemes before they were used as a basis for making the variable assignments. The guiding principle for creating the simple schemes was that the physical properties represented by the DPM variables could not be objectively assessed by sampling at the watershed scale and, therefore, intricate or complex classification schemes could mislead the reader by intimating that more is known about specific hydrologic effects or spatial distribution of soil and vegetative properties that are thought to moderate hydrologic process than is actually known.

Digital geographic data for study-area soils exclusive of SUBASE Bangor soils were based on classification and mapping that has been reported by McMurphy (1980). McMurphy classified soils in the study area by the National Cooperative Soil Survey System (U.S. Department of Agriculture, 1975). Source soil digital data were obtained from the Washington State Department of Natural Resources. Soils of SUBASE Bangor were classified by J. Smith (U.S. Department of Agriculture, Natural Resources Conservation Service, oral commun., 1994) during the early 1990's using the USDA classification system. Source soil digital data for SUBASE Bangor were obtained directly from J. Smith (U.S. Department of Agriculture, Natural Resources Conservation Service, written commun., 1995). Soils mapped according to 
the detailed USDA classification system were reclassified for this investigation using a simple system consisting of three soil types: (1) wildland and agricultural soils formed on glacial till or fine-grained sediments, (2) wildland and agricultural soils formed in glacial outwash and other alluvium, and (3) soils of urban or developed areas. For the DPM simulations, wetland soils were assumed to be hydrologically equivalent to the soils of developed or urban areas because it was thought the rapid hydrologic response of most wetlands, which generally are closely coupled hydrologically to streams, more closely resembles the response of developed or urban soils than they resemble the response of the other two soil types. Wetlands accounted for only a small fraction of the total area of any of the water-balance intensive study areas, as was discussed previously, and lumping of wetland soils with soils of developed or urban areas was thought to result in only small errors in the overall water balance of the intensive study areas.

Source digital data for land-cover classification were taken from land-cover classification and mapping performed for the Puget Sound Regional Council by Economic and Engineering Services, Inc. (Philip Beilin, Snohomish County, written commun., 1994). Classification and mapping had been accomplished using imagery from a 1992 Landsat Thematic Mapper scene. Land cover was reclassified for this investigation according to a simple two-class system: (1) forest vegetation, and (2) nonforest vegetation. All areas with a source land-cover classification of developed or urban or wetland were given the landcover designation of nonforest vegetation for the purpose of DPM simulations.

Digital geographic data were processed using a geographic information system. Soils and land-cover digital coverages were combined to produce a single coverage of hydrologic-response map units (HRMU's) for each water-balance intensive study area, and for the entire study area. Attributes of each HRMU were (1) latitude and longitude of the geographic center of the unit; (2) land area, in square miles; (3) soil type; (4) land slope; and (5) land-cover type. Each HRMU was characterized by a geographically distinct combination of soil type, land slope, and land-cover type, where "geographically distinct" means the combination of soil type, land slope, or land-cover type of the unit was unique among all adjacent units.
The particular soil and land-cover types of each HRMU that were defined under the simplified classification system were used as a basis for assigning values for the DPM variables for characterizing soil physical and vegetation properties of the units.

Variable assignments were generally made on the basis of information that is presented in the published soil survey (McMurphy, 1980), cursory observations, or from results of other investigations that have been conducted in the Puget Sound Lowland. Most of the variables for hydrological characterization, including AVLCAP, SPCYLD, SOLPRM, SLMFAC, EFFLNGTH, EFFSLP, NSOLAS, IROOT, RDMAX, and FCMAX, were assigned before simulations were begun and were not changed during the simulations.

VKSAT, the variable that directly controls the rate of downward drainage below the root zone when soil-water content of the root zone exceeds field capacity, was set to an arbitrary large number (999 in/yr) for soils formed in glacial outwash and other alluvium to reflect the essentially unrestricted drainage that occurs in those soils. VKSAT for soils formed on glacial till or fine-grained sediments was varied among successive simulations in an attempt to minimize the overall water-balance error for all four water-balance intensive study areas. For each successive round of simulations, the same VKSAT value was used in the four intensive study areas for all soils formed on glacial till or fined-grained sediments. The value of VKSAT for soils of developed or urban areas was set to $15 \mathrm{in} / \mathrm{yr}$, which was approximately one-half as large as the VKSAT that was obtained by calibration for glacial-till soils, to reflect the restricted downward drainage from soils of developed or urban areas that was assumed to be caused by impervious surfaces, such as paved roadways, and semiimpervious surfaces, such as lawns and compacted soils. Assignments to the significant remaining hydrological variables, and explanations for the assignments, if needed, are given below.

\section{Variable: AVLCAP}

Definition: Available water capacity, in percent water by soil volume.

Bauer and Mastin (1997) reported soil available water capacities that ranged from 14.6 to 16.6 percent for three soils that were formed on glacial tills of the Puget Sound Lowland. On the basis of those results, soils in the study area that formed on glacial till were assigned 
a value of 15.0 percent for AVLCP. As for soils that formed in glacial outwash and other alluvium, McMurphy (1980) reports available water capacities that range from 3 to 22 percent. Given the wide range of variation of published available water capacity for alluvial soils, no distinction was made between the available water capacities of the glacial till and alluvial soils, and a value of 15.0 percent was assigned to AVLCP for alluvial soils.

\section{Variable: SPCYLD}

Definition: Soil specific yield, in percent water by soil volume.

Bauer and Mastin (1997) presented the only known estimates of the specific yield of soils of the Puget Sound Lowland. Bauer and Mastin reported that soil specific yield ranged from 8.3 to 33 percent for three soils that were formed on glacial tills. Although soil texture and structure would be expected to control both soil specific yield and soil available water capacity, variations of specific yield among the soils studied by Bauer and Mastin did not correlate with variations of soil available water capacity. Nonetheless, a value of 20 percent, which was the average of the specific yields reported by Bauer and Mastin (rounded to the nearest 5 percent), was assigned to SPCYLD for all soils.

\section{Variable: SOLPRM}

Definition: Soil lateral saturated hydraulic conductivity in the direction of the land-slope gradient, in feet per day.

SOLPRM is used by the DPM in a Darcy's law calculation of downslope water flux within the saturated soil profile (Bauer and Mastin, 1997). The authors of this report were unable to find published information for the lateral saturated hydraulic conductivity of the soils that mantled the water-balance intensive study areas. However, when the DPM is applied to areas for which surface runoff is known or can be independently estimated, such as was the case for the intensive study areas in this investigation, the DPM uses SOLPRM effectively to partition runoff from different HRMU's within the area. Thus, a lack of information concerning lateral saturated hydraulic conductivity does not cause the water balance to be in error for an entire water-balance intensive study area, but it does cast doubt on the accuracy of the modeled partitioning of measured surface runoff among HRMU's with different soil types. Because of the lack of specific information concerning soil lateral hydraulic conductivity, SOLPRM was assigned a value of $100 \mathrm{ft} / \mathrm{d}$ for all soil types, which had the effect during simulations of not attempting to use soil lateral hydraulic conductivity to partition surface runoff among HRMU's with different soil types.

\section{Variable: SLMFAC}

Definition: Soil-water-limiting transpiration coefficient, in inches per day.

The variable SLMFAC controls the maximum rate of simulated plant uptake and transpiration when plant uptake is limited by availability of extractable soil water, where availability of such water is expressed as the fraction of soil available water capacity. The DPM is structured to accept different values of SLMFAC that can be obtained from observations of plant uptake and extractable water at any given site (Giles and others, 1985; Bauer and Mastin, 1997). Any actual relation between water uptake by plants and soil-water content can be expected to be complex and dependent on meteorological conditions, plant characteristics, and soil physical properties (Hillel, 1982, p. 301). In keeping with the practice of using simple strategies for depicting poorly known hydrologic processes that was followed in this investigation, SLMFAC was set to an arbitrary value of 5.0 in. per day to prevent the DPM from simulating limitations on plant uptake and transpiration that were induced by availability of extractable soil water until soil water was reduced almost to the specified permanent wilting point. As a result, simulated uptake of soil water and transpiration were generally limited by the maximum transpiration that was specified in the DPM by the Priestley-Taylor equation (Priestley and Taylor, 1972; Bauer and Mastin, 1997).

The Priestley-Taylor coefficient $\alpha$, which serves a function similar to that served by crop coefficients in some other evapotranspiration formulations, such as are discussed by Jensen and others (1990), is equal to 0.73 for forests in the DPM as the model was presented by Bauer and Mastin (1997). This value is near the lower end of the published range of $\alpha$ for coniferous forests (McNaughton and Black, 1973; Shuttleworth and Calder, 1979; Giles and others, 1985); and its use in the model for the conifer-dominated forests of the water-balance intensive study areas was assumed to compensate for any errors in transpiration estimates that were due to the neglect of uptake and transpiration limitations that might have been imposed by availability of extractable soil water. For all other 
vegetation, $\alpha$ was set equal to 1.0 , which is a value that Brutsaert (1982, p. 229) tentatively suggests is appropriate for estimating "... average actual evapotranspiration when the water supply is not severely restricted."

\section{Variable: EFFLNGTH}

Definition: One-half of the average spacing between the smallest drainage channels in a given HRMU, in feet.

EFFLNGTH is used by the DPM with the Darcian calculation of downslope water flux within the saturated soil profile that was described previously to compute the average travel time of soil water to the network of drainage channels. As is the case for SOLPRM, the relative magnitudes of EFFLNGTH are used by the DPM to partition measured runoff among different HRMU's within the modeled area.

EFFLNGTH was assigned a value of $100 \mathrm{ft}$ for all but developed or urban HRMU's, for which EFFLNGTH was set to $5 \mathrm{ft}$ in an attempt to simulate the denser and more efficient drainage networks that are typically found in developed or urban areas, compared with rural areas.

Variable: EFFSLP

Definition: Average land slope between the smallest drainage channels in a given HRMU, expressed as the ratio of vertical to horizontal distance.

Land slope of soil map units described by McMurphy (1980) was used to classify each HRMU according to a classification system consisting of (1) steep slope, and (2) moderate slope. EFFSLP for HRMU's classified as steep slope was assigned a value of 0.3, and EFFSLP for HRMU's classified as moderate slope was assigned a value of 0.1 .

\section{Variable: NSOLAS}

Definition: Soil depth, expressed as the number of 6-inch-thick layers.

The purpose of setting soil depth for this investigation was to establish the reference point for evaluating the equation for unsaturated-zone water balance (eq. 2). For soils formed on glacial till, the appropriate depth was generally fixed by the depth to the top of the cemented till. A survey of soil depth in the glacial-till soil of the Upper Johnson Creek intensive study area yielded an average of $3.5 \mathrm{ft}$ (standard deviation $=0.3 \mathrm{ft}$, $\mathrm{n}=6$ ). A similar survey on glacial till soil near the forest throughfall measurement site (fig. 2) yielded an average soil depth of $3.0 \mathrm{ft}$ (standard deviation $=0.7 \mathrm{ft}$, $\mathrm{n}=5$ ). NSOLAS was assigned a value of 6 for soils that formed on glacial till or fine-grained sediments for areas that were not developed or urban. NSOLAS was assigned a value of 2 for soils of developed or urban areas, which generally were soils formed on glacial till, to reflect the reduced soil thickness in those areas that was caused by erosion and displacement of soils. As for soils that formed in glacial outwash and other alluvium, soil depth should have been fixed by the maximum depth of root penetration, which was not known. A review of the plant root descriptions for the profiles of the alluvial soils of the study area that were described by McMurphy (1980) indicated that a rooting depth estimate of $3 \mathrm{ft}$ was reasonable, and a value of 6 was assigned to NSOLAS for soils formed in glacial outwash and other alluvium.

\section{Variable: IROOT}

Definition: DPM directive for vertical distribution of plant root density (Bauer and Mastin, 1997).

IROOT was assigned a value of 0 for all soil types, which directed the DPM to distribute transpiration potential uniformly with depth in the soil.

\section{Variable: RDMAX}

Definition: Maximum depth of plant roots, in inches. RDMAX was set equal to soil depth.

\section{Variable: FCMAX}

Definition: Foliar coverage, expressed as a fraction of land area.

FCMAX, which is used by the DPM for computing partitioning of evapotranspiration between transpiration and evaporation from the soil surface, was assigned a value of 1.0 for all land-cover types.

Time-series meteorological, interception-loss, and streamflow data, and digital geographic data were assembled and formatted for use in the DPM simulations as described by Bauer and Mastin (1997). Daily simulations were performed for August 1, 1994, to March 31, 1996, for all intensive study areas except the Devils Hole Creek intensive study area, for which simulations were performed for October 1, 1994, to March 31, 1996. Initial average soil-water storage was assumed to equal 10 percent of available water capacity. 


\section{SIMULATED AND MEASURED WATER- BALANCE COMPONENTS FOR THE WATER-BALANCE INTENSIVE STUDY AREAS}

The average 12-month total of downward drainage from the root zone ranged from 11.9 to 16.6 in. among the four water-balance intensive study areas (table 2). The average 12-month totals were computed as the average of two overlapping 12-month periods that began on August 1, 1994, and April 1, 1995, except for the Devils Hole study area, for which the overlapping 12-month periods began on October 1, 1994, and April 1, 1995. Simulated downward drainage from the root zone was greater for the Gamble Creek water-balance intensive study area than it was for the Johnson Creek water-balance intensive study area, despite the fact that average 12-month precipitation was 13 percent greater for the Johnson Creek intensive study area than it was for the Gamble Creek study area. Approximately 30 percent of the soils of the Gamble Creek intensive study area were formed in glacial outwash and other alluvium that promote rapid drainage to the water table. Almost all of the soils of the Johnson Creek intensive study area were formed on glacial till, which tended to retard vertical drainage and to promote direct runoff. Estimated direct runoff from the Gamble Creek intensive study area, which was computed from measured discharge and estimated base flow and expressed as an equivalent depth of water, was less than one-half as large as direct runoff from the Johnson Creek intensive study area. The difference in estimated runoff and the resultant difference in simulated downward drainage below the root zone could have been caused in part by errors in estimates of base flow.

Most of the precipitation and simulated downward drainage from the root zone, when they were averaged among the four intensive study areas and by month of the calendar year, occurred during late autumn, winter, and early spring (fig. 8). The months of November through March accounted for 73 percent of the calendar-year precipitation and for 84 percent of the calendar-year downward drainage below the root zone. December accounted for about one-fourth of the calendar-year total precipitation and drainage.

One aspect of model performance that was amenable to evaluation was simulated soil-water storage. The evaluation of model performance was accomplished by comparing measured soil-water storage with simulated soil-water storage for the soilwater storage measurement site in the Upper Johnson Creek intensive study area. Measured soil-water storage for each station at that site is presented in table 3. An adjustment had to be made to simulated soil-water storage to place it on an equal basis with measured soil-water storage. Measured soil-water storage includes all moisture in the soil profile, whereas the DPM computes water storage in terms of available water, which is the amount of water in excess of the soil-water wilting point (Bauer and Mastin, 1997). Simulated soil-water storage was adjusted by adding 3 in. of water, which was the approximate annual minimum of measured soil-water content for the site that was monitored (fig. 9).

Measured and simulated soil-water storage were compared for the soil-moisture measurement site that was in the Upper Johnson Creek intensive study area. The soil type of the HRMU in the simulation was "soils formed on glacial till." The land-cover type was "forest" and the slope was classified as "moderate." Simulated soil-water storage appeared to exhibit a larger seasonal amplitude of variation than did measured soil-water storage, which could indicate that the available water capacity of the soil represented in the DPM simulation was too large to match the actual capacity of the soil in the Upper Johnson Creek intensive study area (fig. 9). The measurements, however, indicated soil-water storage varied considerably from station to station. Because of the inherent variability of soil-water storage at the landscape scale and uncertainty about the actual available water capacity, the apparent disagreement between simulated and measured soil-water storage was considered to be acceptable. 
Table 2. Water-balance components computed in conjunction with Deep Percolation Model simulations of the near-surface water balance of the water-balance intensive study areas

[ $P$, precipitation; $R_{o}$, direct runoff; $E_{s}$, evaporation from soil surface; $E_{t}$, plant transpiration; $E_{i}$, evaporation from plant surfaces of precipitation that has been intercepted and stored on those surfaces; $\Delta S$, change of water storage in the root zone; $D$, rate of downward flow of water below the root zone]

\begin{tabular}{|c|c|c|c|c|c|c|c|}
\hline Intensive study area & $\begin{array}{l}\text { 12-month } \\
\text { simulation } \\
\text { period }\end{array}$ & $\begin{array}{c}P \\
\text { (inches) }\end{array}$ & $\begin{array}{c}R_{o} \\
\text { (inches) }\end{array}$ & $\begin{array}{l}E_{s}+E_{t}+E_{i} \\
\quad \text { (inches) }\end{array}$ & $\begin{array}{c}\Delta S \\
\text { (inches) }\end{array}$ & $\begin{array}{c}D \\
\text { (inches) }\end{array}$ & $\begin{array}{l}\text { Water- } \\
\text { balance } \\
\text { error } \\
\text { (inches) }\end{array}$ \\
\hline \multirow[t]{3}{*}{ Upper Johnson Creek } & $\begin{array}{l}\text { August } 1994 \text { to } \\
\text { July } 1995\end{array}$ & 50.5 & 16.3 & 21.0 & -0.5 & 13.4 & 0.3 \\
\hline & $\begin{array}{l}\text { April } 1995 \text { to } \\
\text { March } 1996\end{array}$ & 43.4 & 6.3 & 24.2 & 0.0 & 12.3 & 0.6 \\
\hline & ${ }^{1}$ Average & 47.0 & 11.3 & 22.6 & -0.3 & 12.9 & 0.5 \\
\hline \multirow[t]{3}{*}{ Johnson Creek } & $\begin{array}{l}\text { August } 1994 \text { to } \\
\text { July } 1995\end{array}$ & 50.2 & 17.0 & 20.6 & -0.5 & 13.1 & 0.0 \\
\hline & $\begin{array}{l}\text { April } 1995 \text { to } \\
\text { March } 1996\end{array}$ & 43.3 & 10.9 & 23.8 & -2.4 & 12.0 & -1.0 \\
\hline & ${ }^{1}$ Average & 46.8 & 14.0 & 22.2 & -1.5 & 12.6 & -0.5 \\
\hline \multirow[t]{3}{*}{ Gamble Creek } & $\begin{array}{l}\text { August } 1994 \text { to } \\
\text { July } 1995\end{array}$ & 43.7 & 7.5 & 19.6 & -1.0 & 16.6 & 1.0 \\
\hline & $\begin{array}{l}\text { April } 1995 \text { to } \\
\text { March } 1996\end{array}$ & 38.9 & 5.7 & 22.9 & -2.5 & 13.7 & -0.9 \\
\hline & ${ }^{1}$ Average & 41.3 & 6.6 & 21.3 & -1.8 & 15.2 & 0.1 \\
\hline \multirow[t]{3}{*}{ Devils Hole Creek } & $\begin{array}{l}\text { October } 1994 \text { to } \\
\text { September } 1995\end{array}$ & 52.1 & 15.5 & 21.3 & -0.9 & 15.3 & 0.9 \\
\hline & $\begin{array}{l}\text { April } 1995 \text { to } \\
\text { March } 1996\end{array}$ & 42.3 & 12.0 & 21.2 & -2.2 & 11.9 & -0.6 \\
\hline & ${ }^{1}$ Average & 47.2 & 13.8 & 21.3 & -1.6 & 13.6 & 0.2 \\
\hline
\end{tabular}

${ }^{1}$ Averages are for two 12 -month periods. 

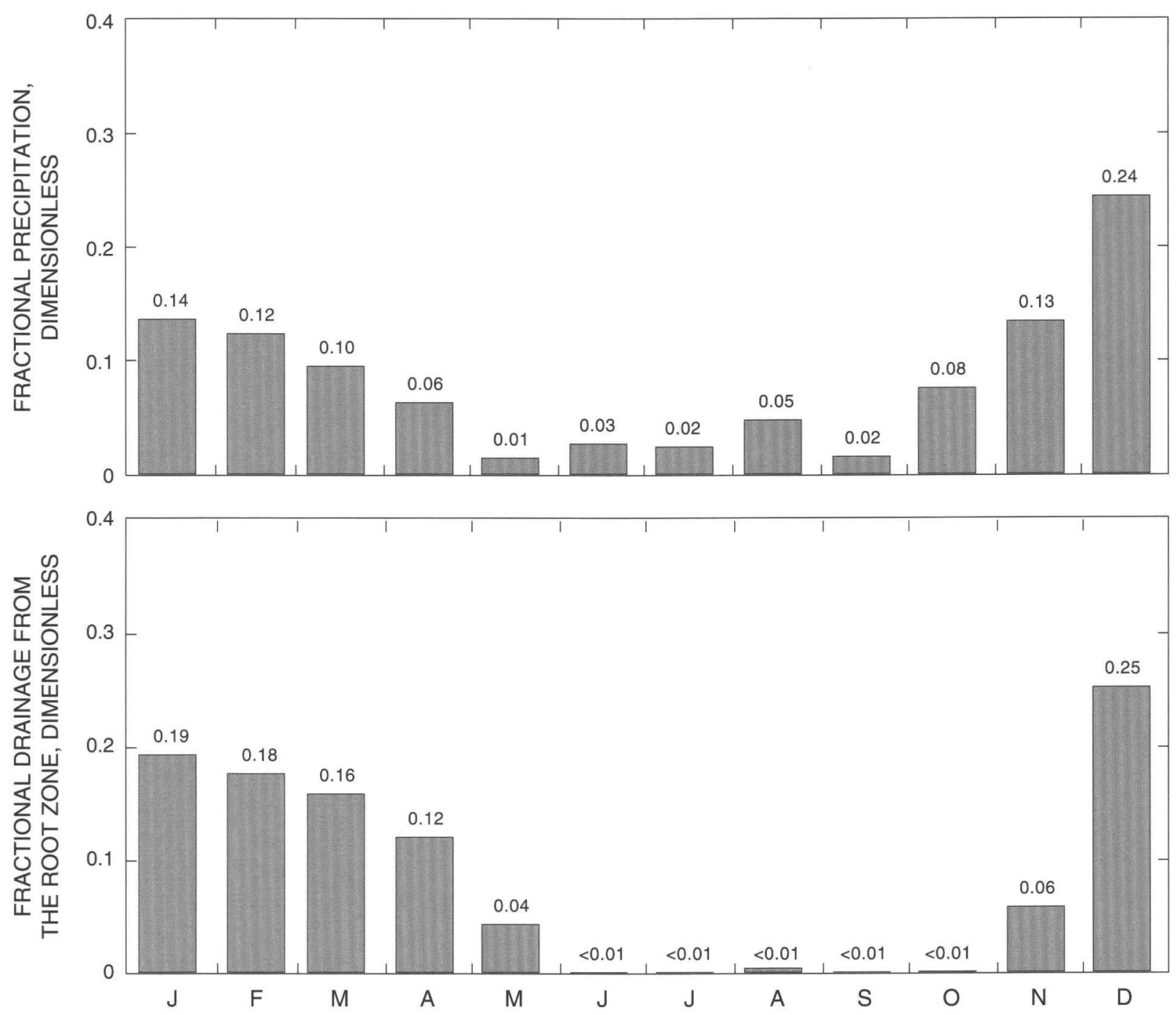

Figure 8. Monthly precipitation and simulated drainage from the root zone, averaged among soil and land-cover types for the four water-balance intensive study areas, and expressed as a fraction of the 12-month average. 
Table 3. Soil-water storage as measured at four stations in the Upper Johnson Creek water-balance intensive study area

[values are in inches of water; --, missing data]

\begin{tabular}{ccccc}
\hline & \multicolumn{4}{c}{ Station number } \\
\cline { 2 - 5 } $\begin{array}{c}\text { Date } \\
\text { (month, day, year) }\end{array}$ & 1 & 2 & 3 & 4 \\
\hline 10-21-1994 & 3.5 & 2.4 & -- & -- \\
$11-18-1994$ & 8.0 & 5.8 & 7.9 & 7.1 \\
$02-16-1995$ & 8.1 & -- & -- & 8.2 \\
$03-16-1995$ & 8.6 & 8.6 & 10.2 & -- \\
$03-28-1995$ & 10.4 & 8.0 & 8.2 & 4.9 \\
$04-26-1995$ & 7.6 & 7.5 & 7.9 & 4.2 \\
$05-26-1995$ & 6.5 & 6.2 & 6.2 & 4.0 \\
$06-20-1995$ & 6.1 & 5.0 & 5.2 & 3.9 \\
$07-12-1995$ & 5.0 & 4.3 & 4.7 & 3.2 \\
$08-23-1995$ & 6.3 & 4.1 & 5.5 & 4.1 \\
$09-26-1995$ & 4.3 & 3.7 & 4.6 & 2.9 \\
$10-24-1995$ & 7.1 & 4.0 & 6.7 & 5.9 \\
$11-28-1995$ & 8.7 & 3.9 & 9.6 & 11.1 \\
$01-31-1996$ & -- & -- & 9.6 & 5.7 \\
$02-16-1996$ & -- & -- & -- & 6.5 \\
\hline
\end{tabular}

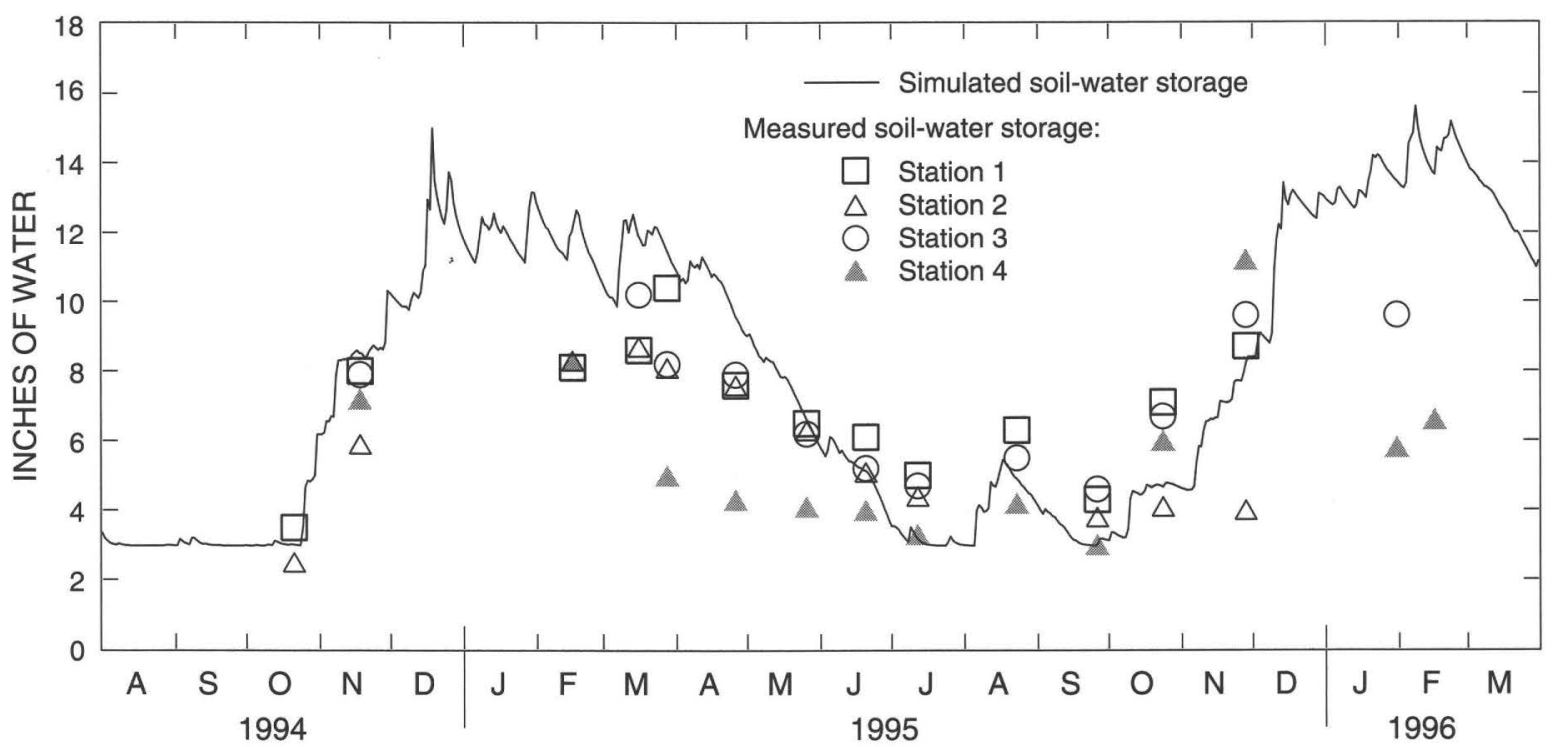

Figure 9. Measured and simulated soil-water storage for a site within the Upper Johnson Creek waterbalance intensive study area during August 1, 1994 to March 31, 1996. 


\section{ESTIMATING ANNUAL RECHARGE FOR THE STUDY AREA}

Precipitation is the dominant source of water recharging ground water in the study area, and it is reasonable to expect variations in annual recharge to be related to variations in annual precipitation. Factors such as permeability of the subsoil materials and the land-cover characteristics also could affect the nearsurface water balance, and ultimately recharge; therefore, the relation between precipitation and recharge could vary according to soil and land-cover characteristics.

Plots of DPM-simulated 12-month downward drainage from the root zone against 12-month precipitation were used to develop predictive equations for estimating annual recharge from annual precipitation. This approach assumed the 12-month totals of downward drainage from the root zone were equivalent to annual recharge as was discussed in the "Introduction" section. The term "annual" is used in the sense the water-balance components were derived from analysis of a complete annual cycle. Data pairs plotted were grouped according to combinations of soil and land-cover types identified in each water-balance intensive study area. The percentage of land area in steep slopes averaged only 10.3 among the four intensive study areas, and land slope was ignored in the grouping. One data pair was plotted for each soil and land-cover combination for each intensive study area that contained the combination, and the pair represented the averages of annual recharge and precipitation within an intensive study area for the identified combination (fig. 10). Lines were fit by eye through points for each group of soil and land-cover types that appeared to be distinct in the plot. The point on the annual precipitation axis where annual recharge was 0 was taken to be the average of such values from table 5, equations 3 and 6 of Vaccaro and others (1998), who examined annual recharge for several watersheds in the Puget Sound Lowland. For this investigation, annual recharge was assumed to equal 0 when annual precipitation was 11 in. Equations were determined from graphical analysis of the lines, and one equation was developed for each soil-and-land-cover group (table 4). In developing the predictive equations for recharge, it was assumed that recharge was 0 for areas of open water and for wetlands. The recharge predictive equations were identical for both forest and nonforest land-cover types on soil formed on glacial till or fine-grained sediments, resulting in a reduced geographic classification system that consisted of the five soil-and-land-cover groups given in table 4 .

Table 4. Relations for predicting annual recharge to ground water from annual precipitation

\begin{tabular}{ll}
\hline $\begin{array}{l}\text { Soil and land-cover group } \\
\text { Nonforest vegetation on soils formed on } \\
\text { glacial outwash and other alluvium }\end{array}$ & $\begin{array}{l}\text { Equation for predicting annual recharge } \\
(R, \text { in inches }) \text { as a function of annual } \\
\text { precipitation }(P, \text { in inches })\end{array}$ \\
$\begin{array}{l}\text { Forest vegetation and soils formed on } \\
\text { glacial outwash and other alluvium }\end{array}$ & $R=0.806-8.87$ \\
$\begin{array}{l}\text { Forest and nonforest vegetation on soils } \\
\text { formed on glacial till or fine-grained sediments }\end{array}$ & $R=0.633 P-6.96$ \\
$\begin{array}{l}\text { Developed or urban land } \\
\text { Water and wetlands }\end{array}$ & $R=0.388 P-4.27$ \\
\hline
\end{tabular}




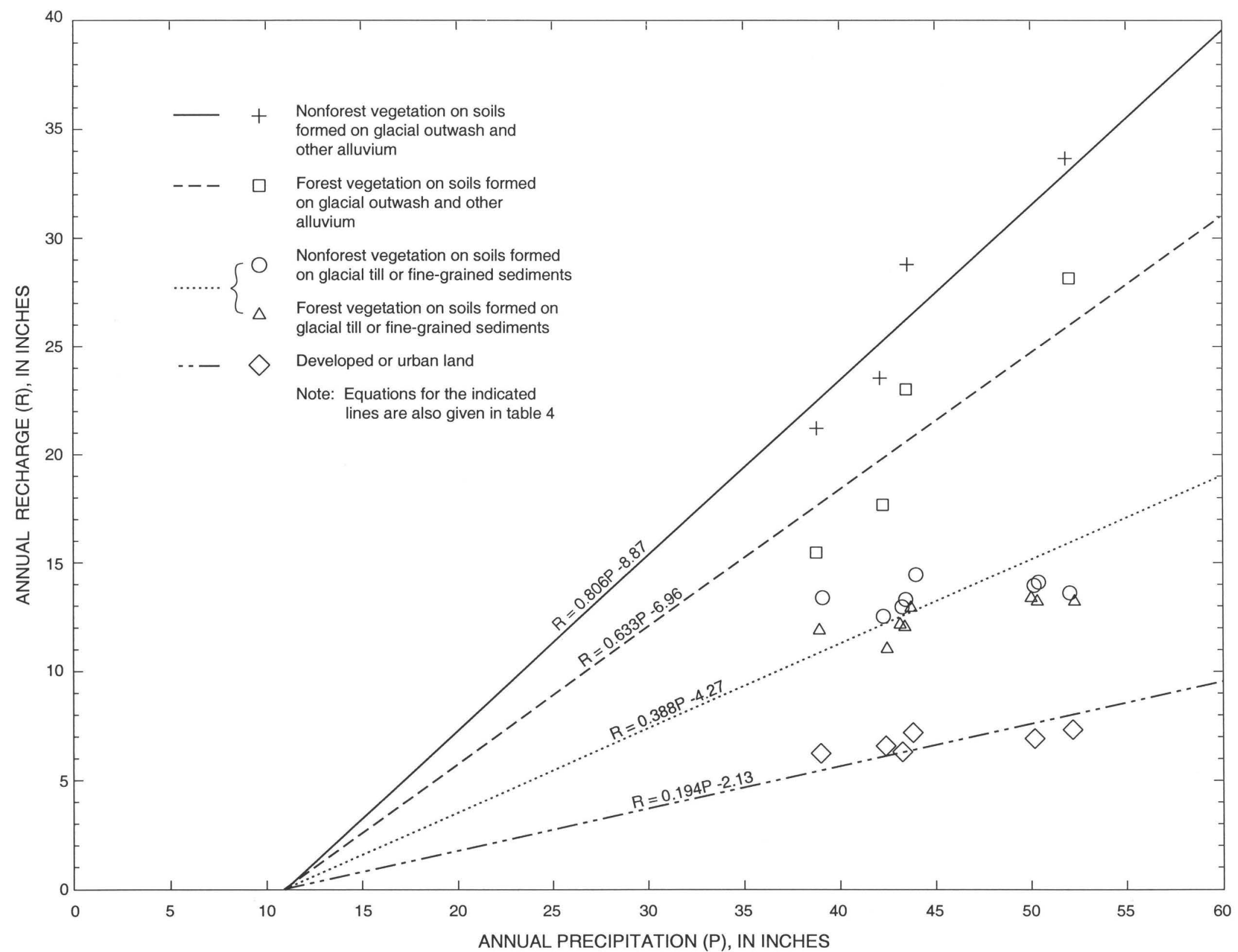

Figure 10. Annual recharge for selected combinations of soil and land-cover types, annual precipitation, and lines depicting relations between annual recharge and annual precipitation. 
Table 5. Measured and estimated annual precipitation at Bremerton for calendar years 1953 to 1995

\begin{tabular}{|c|c|c|c|}
\hline Year & $\begin{array}{l}\text { Annual } \\
\text { precipitation } \\
\text { (inches) }^{1}\end{array}$ & Year & $\begin{array}{l}\text { Annual } \\
\text { precipitation } \\
\text { (inches) }{ }^{1}\end{array}$ \\
\hline 1953 & 60.59 & 1975 & 64.55 \\
\hline 1954 & 56.27 & 1976 & 38.79 \\
\hline 1955 & 54.75 & 1977 & 48.70 \\
\hline 1956 & 50.59 & 1978 & 44.02 \\
\hline 1957 & 44.68 & 1979 & 47.59 \\
\hline 1958 & 48.53 & 1980 & 52.62 \\
\hline 1959 & 49.74 & 1981 & 53.25 \\
\hline 1960 & 51.13 & 1982 & 53.92 \\
\hline 1961 & 60.83 & 1983 & 70.91 \\
\hline 1962 & 46.14 & 1984 & 49.74 \\
\hline 1963 & 49.35 & 1985 & 133 \\
\hline 1964 & 49.56 & 1986 & 55.62 \\
\hline 1965 & 43.03 & 1987 & 48.07 \\
\hline 1966 & 52.72 & 1988 & 47.49 \\
\hline 1967 & 150 & 1989 & 145 \\
\hline 1968 & 164 & 1990 & 162 \\
\hline 1969 & 45.79 & 1991 & 152 \\
\hline 1970 & 149 & 1992 & 146 \\
\hline 1971 & 49.81 & 1993 & 140 \\
\hline 1972 & 160 & 1994 & 63.24 \\
\hline 1973 & 56.63 & 1995 & 168 \\
\hline 1974 & 57.28 & & \\
\hline
\end{tabular}

${ }^{1}$ The following rules were used to estimate annual precipitation at Bremerton for years with incomplete monthly records:

A. If data for fewer than 3 months were missing for a year, precipitation measured at nearby Wauna for the missing months was added to the available Bremerton record to compute annual precipitation.

B. If data for 3 or more months were missing for a year, annual precipitation at Bremerton was computed using the regression equation: $P_{\text {Bremerton }}=5.28+0.93 P_{\text {Wauna }}$, where $P_{\text {Bremerton }}$ is annual precipitation measured at Bremerton, in inches; and $P_{\text {Wauna }}$ is annual precipitation measured at Wauna, in inches; and the regression equation was developed by simple linear regression analysis of available total annual precipitation for Bremerton and Wauna for 1980 to 1994.

The study-area map of soil-and-land-cover groups was used with the equations for annual recharge to produce a map that, when combined with data for total annual precipitation, can be used to generate a study-area map of annual recharge. Because the intent was to enable the making of an historical map of recharge using historical precipitation records, precipitation measured at the temporary meteorological stations was compared with contemporaneous precipitation at the long-term climatological station at Bremerton. Annual precipitation at Bremerton for 1953 to 1995 is listed in table 5. The study area was divided into three precipitation zones, with one zone corresponding to each of the three temporary meteorological stations. Each precipitation zone was assigned a precipitation factor $\left(P_{f}\right)$ equal to the ratio of total precipitation at a respective temporary station to contemporaneous precipitation at the Bremerton station. Precipitation was greater at Bremerton than at the local stations, and $P_{f}$ ranged from 0.61 to 0.71 among the three precipitation zones. Finally, the study-area map of HRMU's was combined with the map of precipitation zones to produce a key that, when combined with the recharge predictive equations (table 4), can be used to generate a map of annual recharge based on annual precipitation at Bremerton (fig. 11). An example of a map of average annual recharge for the study area that can be produced using the procedures described previously is presented on figure 12 . The map of average annual recharge is based on average annual precipitation at Bremerton for 1953 to 1995. 


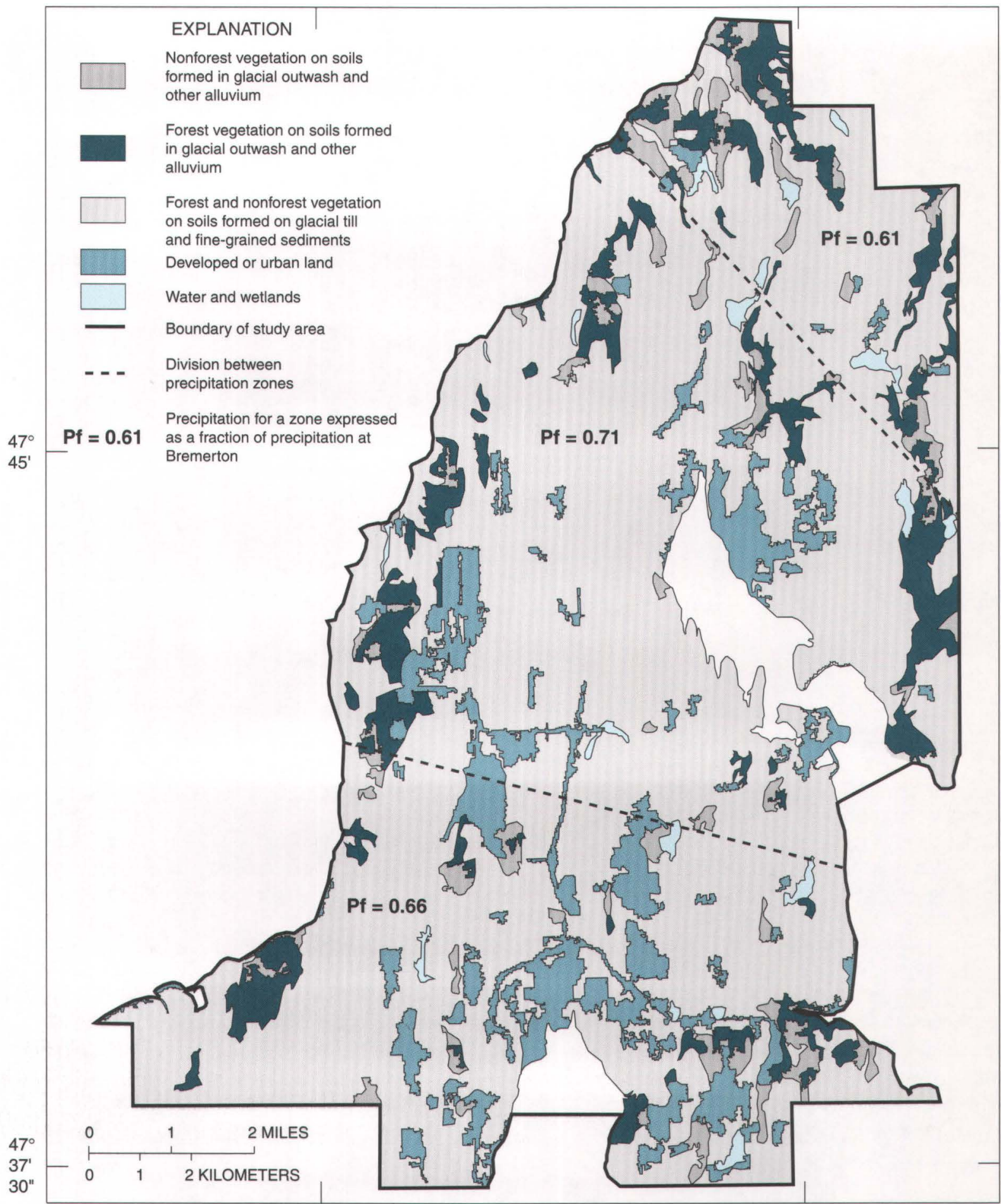

Figure 11. Soil and land-cover groups and precipitation zones. 


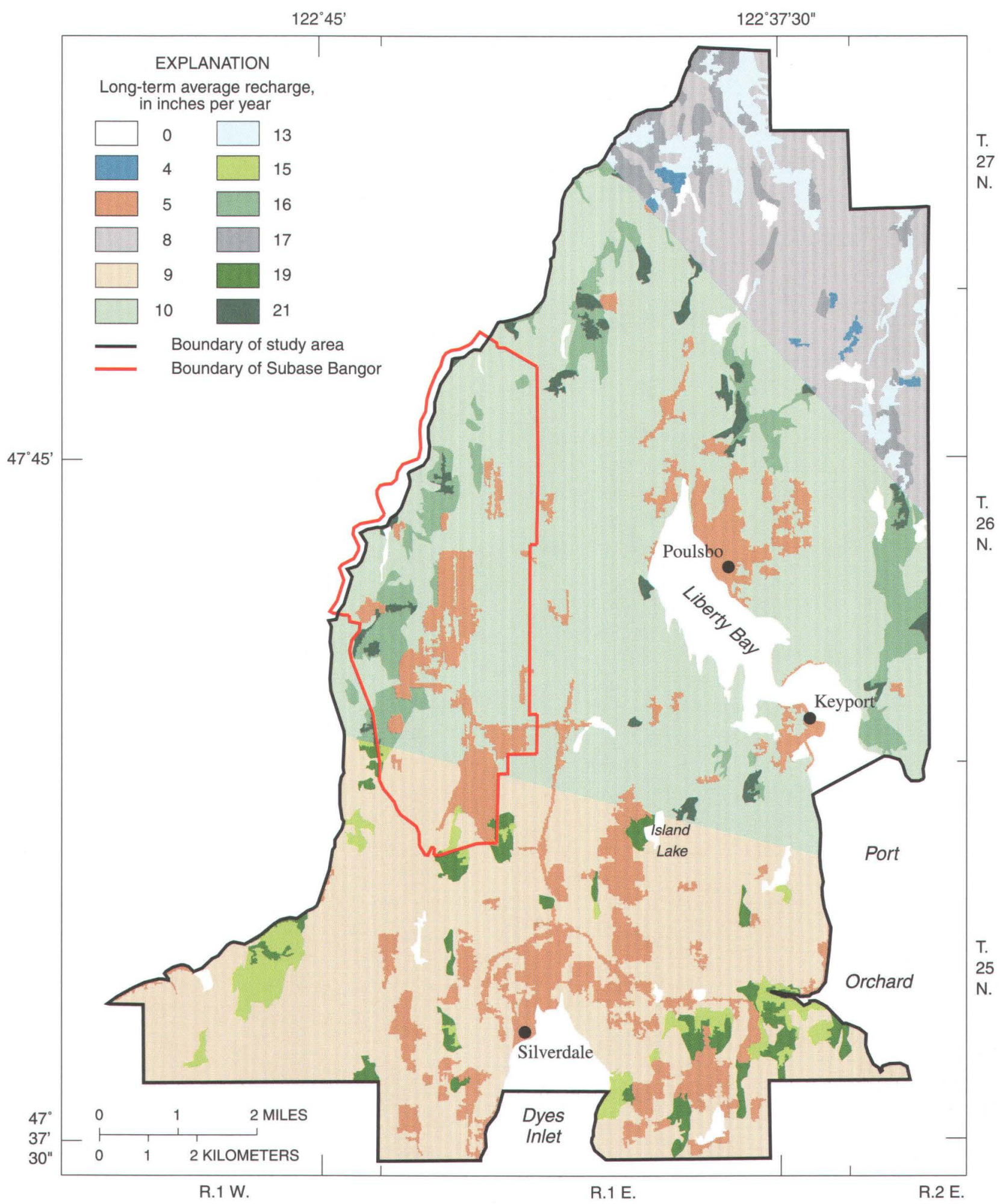

Figure 12. Long-term average annual recharge in inches per year, based on average annual precipitation at Bremerton during 1953 to 1995. 


\section{SOME SOURCES OF UNCERTAINTY IN THE RECHARGE ESTIMATES}

Estimates of annual recharge that are made by applying the equations of table 4 to the appropriate areas depicted on figure 11 are subject to numerous uncertainties. Although the uncertainties could not be quantified, their major sources nonetheless warrant discussion. Sources of uncertainty, once identified, can become the focus of future investigations aimed at improving understanding of physical processes that regulate recharge to ground water. Interception loss is an important regulating process for forested regions, and the detailed treatment of that process in this report is an example of how an investigation can contribute to the understanding of such processes.

Sources of uncertainty in recharge estimates developed using the recharge predictive equations and figure 11 fall into three main groups: (1) factors and conditions that affect reliability of estimates of downward drainage below the root zone as simulated with the DPM; (2) assumptions concerning equivalency of downward drainage from the root zone and recharge to ground water; and (3) assumptions involved with scaling up results from the water-balance intensive area studies to estimate annual recharge for the entire study area.

Because results from DPM modeling of the nearsurface water balance in the intensive study areas were used in development of the predictive equations for recharge that were applied to the entire study area, errors in DPM results ultimately were manifested in recharge estimates for the study area. There are several sources of error for water-balance components that were derived for the intensive study areas, including the sources listed below:

- An objective means for computing direct runoff $\left(R_{o}\right)$ from total discharge $(Q)$ was not available and subjective estimates of base flow were used in computing $R_{o}$. Errors in $R_{o}$ for any intensive study area can be expected to contribute directly to errors in DPM-simulated water-balance components such as $\Delta S$ and $D$.

- Errors in assignments to DPM variables used to characterize soil and plant properties could have caused errors in the modeled partitioning of the water balance among $R_{o}, \Delta S$, evapotranspiration, $D$, and ultimately recharge.

- Little published information exists concerning evapotranspiration in western Washington with which to verify that evapotranspiration estimates were accurate. Simulated evapotranspiration accounted for a substantial percentage (41 to 59 percent) of precipitation on a 12-month basis, and the percentage error in $D$ that was computed from the water balance would have been larger than the percentage error in evapotranspiration. For example, a 10-percent error in evapotranspiration would yield errors in $D$ that would range from 12 to 20 percent among the intensive study areas on a 12-month basis.

- Apparently, little is known about effects of impervious surfaces on area-average waterinfiltration rates for the Pacific Northwest. Impervious areas, such as parking lots, roadways, and sidewalks likely did increase area-average $R_{o}$ for highly developed areas; however, those surfaces likely reduced evapotranspiration for those areas as well. The net effect of impervious surfaces on annual recharge would depend on whether or not increases in $R_{o}$ were offset by the attendant decreases in evapotranspiration.

The practice of estimating recharge to ground water on the basis of downward flow below the root zone also could lead to errors in recharge. In most environments, water that percolates below a few meters from the soil surface is destined to recharge a saturated system (extremely arid environments can be an exception). A question remains: Which saturated system is the downward-flowing water destined to reach? The profile of a hydrogeologic system can contain multiple unsaturated zones that are separated by water-saturated zones. The arrangement and thicknesses of saturated and unsaturated zones in any given profile could be intricate and could change with time. Because of practical limits that exist for intensity of hydrogeologic sampling; however, some of the interbedded and possibly transient saturated zones can remain undetected during investigation of the structure of hydrogeologic systems. As a result, not all of the water that percolates downward below a root zone necessarily arrives as recharge at the uppermost saturated zone that has been identified in the hydrogeologic framework. For example, water percolating through predominantly unsaturated materials below a root zone, upon meeting a layer of fine-grained sediments with small hydraulic conductivity, could recharge a thin saturated zone, flow laterally, and discharge to a stream. The water in this example might not reach the saturated ground-water system that has been identified as part of the 
hydrogeologic framework. Estimates of recharge to a deep saturated system that are developed from analysis of the near-surface water balance could be too large if some or all of the water that drains from the root zone is shunted to a stream before it reaches the deep system.

Assumptions inherent in the practice of scaling up results from the intensive water-balance studies to estimate annual recharge for the entire study by using equations that predict annual recharge as a function of annual precipitation are additional sources of uncertainty for the recharge estimates. Some examples of sources are

- The actual relation between annual precipitation and annual recharge could vary with the seasonal distribution of precipitation, yet, such temporal detail is not accounted for by the predictive equations, which are based on annual totals.

- The relation between annual recharge and annual precipitation might not be linear throughout the historical range of annual precipitation. As a result, recharge predicted from annual precipitation that is outside the range of precipitation used to develop the predictive equations could be in error.

- Errors in annual precipitation would lead to errors in estimated annual recharge. There are several sources of annual precipitation error that are germane to the recharge estimates. The first of these is measurement error for precipitation at Bremerton and at the temporary meteorological stations. A second source is sampling error that could be caused by year-to-year variations in the relation between annual precipitation at Bremerton and at the sites of the three temporary meteorological stations. A third source is sampling error that is caused by annual precipitation varying throughout the study area in ways that are not depicted by the three precipitation zones (fig. 11). Because precipitation was the largest component of the annual water balance, relatively small errors in that component can cause substantial errors in estimates of annual recharge. For annual precipitation of 45 in., a 10-percent error in precipitation would lead to errors in annual recharge that range from $1 \mathrm{in}$. for developed or urban land to 4 in. for nonforest vegetation on soils formed in glacial outwash and other alluvium.
- There is considerable scatter about the lines for the recharge predictive equation (fig. 10). The scatter, combined with possible errors in the precipitationaxis intercepts that were adopted, contribute to uncertainty concerning the accuracy of the predictive equations.

\section{SUMMARY AND CONCLUSIONS}

An investigation was made to estimate recharge to ground water from precipitation that could be incorporated into the boundary conditions for numerical simulation of ground-water flow in the vicinity of SUBASE Bangor. The approach taken was to estimate downward flow below the plant root zone from the water balance, where the downward flow was assumed to equal recharge to ground water, for four water-balance intensive study areas, and to use the recharge estimates to develop predictive equations that could be used to estimate annual recharge for the entire study area.

Analysis of the water balance for the four intensive study areas was made using the Deep Percolation Model (Bauer and Vaccaro, 1987), as modified by Bauer and Mastin (1997). The waterbalance modeling was supported by field measurements of precipitation, surface-water discharge, volumetric soil-water content, global solar radiation, and air temperature. Original geographic data sets for soils and land cover were reclassified using simplified schemes before they were used as a basis for making the variable assignments. The intensive study areas were then mapped according to three soil types, two land-slope classes, and two landcover types, and the mapping was used as a basis for assignments to DPM variables that characterize soil and vegetation physical properties that are important for partitioning the water balance. A combination of measured and simulated water-balance components was used to estimate rate of downward drainage below the root zone for each combination of soil type, slope class, and land-cover type that was present in each intensive study area.

A study of interception loss from an approximately 80 -year-old stand of Douglas-fir was made to develop a better understanding of evaporative losses from wetted conifer foliage in the coniferdominated study area. The canopy of the stand had a project leaf area index of approximately 10 . The investigation yielded a physically based procedure for 
predicting interception loss, and it revealed that interception losses from the stand accounted for approximately 20 percent of the precipitation that was measured near the stand during January 1995 to March 1996.

The water-balance simulations encompassed the period of August 1994 to March 1996, and waterbalance components were averaged for overlapping 12-month periods for each area. For the Upper Johnson Creek, Johnson Creek, and Gamble Creek waterbalance intensive study areas, the first 12-month period began August 1, 1994, and the second 12-month period began April 1, 1995. For the Devils Hole waterbalance intensive study area, the first 12-month period began October 1, 1994, and the second 12-month period began April 1, 1995. Area-averaged 12-month precipitation ranged from 38.9 to 52.1 in. per year among the four intensive study areas, and areaaveraged 12-month downward drainage below the root zone, which was taken to be an appropriate surrogate for 12-month recharge, ranged from 11.9 to $16.6 \mathrm{in}$. per year. The water-balance components, when averaged for either of the 12-month simulation periods, were considered to be annual averages in the sense that they were computed from analysis of one complete annual cycle.

The relation between annual precipitation and annual recharge was explored for each combination of soil and land-cover types that was present in the intensive study areas. Predictive equations for annual recharge that were written in terms of annual precipitation were developed for each of four soil and land-cover combinations that exhibited a unique recharge response to precipitation. The entire study area was remapped according to five soil-and-landcover groups (the four combinations plus a group for water and wetland). The soil-and-land-cover map can be used with the equations to produce spatially distributed estimates of annual recharge for the study area based on annual precipitation. The soil-and-landcover map is divided into three precipitation zones.

The amount of precipitation that was measured within each zone during the 20-month investigation, expressed as a fraction of the contemporaneous precipitation at a long-term station at Bremerton, provides a means for estimating historical annual precipitation for each zone.

Some of the potentially important sources of uncertainty in recharge estimates made using the above-described map and the recharge equations are: (1) factors that affected reliability of estimates of downward drainage below the root zone as simulated with the DPM, such as uncertainties in soil and plant properties that were used to make DPM variable assignments and that affect water-balance partitioning; (2) assumptions concerning equivalency of downward drainage from the root zone and recharge to ground water; and (3) assumptions involved with scaling up results from the water-balance intensive studies to estimate annual recharge for the entire study area.

\section{REFERENCES CITED}

Bauer, H.H., and Mastin, M.C., 1997, Recharge from precipitation in three small, glacial-till-mantled catchments in the Puget Sound Lowland, Washington: U.S. Geological Survey Water-Resources Investigations Report 96-4219, 119 p.

Bauer, H.H., and Vaccaro, J.J., 1987, Documentation of a deep percolation model for estimating ground-water recharge: U.S. Geological Survey Open-File Report 86-536, $180 \mathrm{p}$.

Becker, J.E., 1995, Quantitative flow system analysis through numerical modeling techniques of the Bangor Aquifer Systems, Kitsap County, Washington: Tacoma, Wash., Robinson and Noble, Inc., prepared for Kitsap County Public Utility District No. 1, 145 p.

Brutsaert, W., 1982, reprinted with corrections, 1984, Evaporation into the atmosphere: Boston, D. Reidel, $299 \mathrm{p}$.

Campbell, G.S., 1977, An introduction to environmental biophysics: New York, Springer-Verlag, 159 p. 1985, Soil Physics with BASIC: New York, Elsevier, $150 \mathrm{p}$.

Fritschen, L.J., Hsia, J., and Doraiswamy, P., 1977, Evapotranspiration of a Douglas fir determined with a weighing lysimeter: Water Resources Research, v. 13, p. 145-148.

Garling, M.E., Molenaar, Dee, and others, 1965, Water resources and geology of the Kitsap Peninsula and certain adjacent islands: Olympia, Wash., Washington State Department of Conservation Water Supply Bulletin no. 18, $309 \mathrm{p}$.

Gash, J.H.C., and Morton, A.J., 1978, An application of the Rutter model to the estimation of the interception loss from Thetford Forest: Journal of Hydrology, v. 38, p. $49-58$.

Gee, G.W., Fayer, M.J., Rockhold, M.L., and Campbell, M.D., 1992, Variations in recharge at the Hanford Site: Northwest Science, v. 66, p. 237-250.

Giles, D.G., Black, T.A., and Spittlehouse, D.L., 1985, Determination of growing season soil water deficits on a forested slope using water balance analysis: Canadian Journal of Forest Research, v. 15, p. 107-114. 
Hart Crowser, Inc., 1988, Current situation report, site A, Naval Submarine Base, Bangor, Washington: Seattle, Wash., Hart Crowser, Inc., prepared for Pacific Northwest Branch Office, Western Division, Naval Facilities Engineering Command, Silverdale, Washington, v. 1.

Hillel, D., 1982, Introduction to soil physics: Orlando, Fla., Academic Press, 364 p.

Jensen, M.E., Burman, R.D., and Allen, R.G., eds., 1990, Evapotranspiration and irrigation water requirements: New York, American Society of Civil Engineers, ASCE Manuals and Reports on Engineering Practice, no. 70, $332 \mathrm{p}$.

Jones, M.A., 1996, Thickness of unconsolidated deposits in the Puget Sound Lowland, Washington and British Columbia: U.S. Geological Survey Water-Resources Investigation Report 94-4133, 1 pl., scale 1:500,000.

Kitsap County Ground Water Advisory Committee, Economic and Engineering Services, Inc., Hart Crowser Inc., Pacific Groundwater Group, and Robinson and Noble, Inc., 1991, Kitsap County ground water management plan, Grant no. 1, Background data collection and management issues: Olympia, Wash., Economic and Engineering Services, Inc., $2 \mathrm{v}$.

Lowe, P.R., 1977, An approximating polynomial for the computation of saturated vapor pressure: Journal of Applied Meteorology, v. 16, p. 100-103.

McMurphy, C.J., 1980, Soil survey of Kitsap County area, Washington: U.S. Department of Agriculture, Soil Conservation Service, 127 p., 31 sheets.

McNaughton, K.G., and Black, T.A., 1973, A study of evapotranspiration from a Douglas fir forest using the energy balance approach: Water Resources Research, v. 9, p. 1,579-1,590.

Monteith, J.L., 1965, Evaporation and environment, in Fogg, G.E., ed., The state and movement of water in living organisms: New York, Academic Press, Symposium no. 19 of the Society for Experimental Biology, v. 19, p. 205-234.

Owenby, J.R., and Ezell, D.S., 1992, Monthly station normals of temperature, precipitation, and heating and cooling degree days, 1961-1990, Climatography of the United States no. 81: Asheville, N.C., National Oceanic and Atmospheric Administration, 30 p.

Penman, H.L., 1956, Evaporation-An introductory survey: Netherlands Journal of Agricultural Sciences, ser. A, v. 4 , p. 9-29.

Pilgrim, D.H., and Cordery, I, 1992, Flood runoff, in Maidment, D.R., ed., Handbook of Hydrology: New York, McGraw-Hill, p. 9.1-9.42.

Priestley, C.H.B., and Taylor, R.J., 1972, On the assessment of surface heat flux and evaporation using large-scale parameters: Monthly Weather Review, v. 100, p. 81-92.

Puget Sound Council of Governments, 1988, Population and employment forecasts: Seattle, Wash., Puget Sound
Council of Governments, Information Center, about $200 \mathrm{p}$.

Rhia, S.J., and Campbell, G.S., 1985, Estimating water fluxes in Douglas-fir plantations: Canadian Journal of Forest Research, v. 15, p. 701-707.

Rothacher, J., 1963, Net precipitation under a Douglas-fir forest: Forest Science, v. 9, p. 423-429.

Running, S.W., and Coughlan, J.C., 1988, A general model of forest ecosystem processes for regional applications-I. Hydrologic balance, canopy gas exchange and primary production processes: Ecological Modelling, v. 42, p. 124-154.

Rutter, A.J., Kershaw, K.A., Robins, P.C., and Morton, A.J., 1971, A predictive model of rainfall interception in forests-I. Derivation of the model from observations in a plantation of Corsican pine: Agricultural Meteorology, v. 9, p. 367-384.

Rutter, A.J., Morton, A.J., and Robins, P.C., 1975, A predictive model of rainfall interception in forests-II. Generalization of the model and comparison with observations in some coniferous and hardwood stands: Journal of Applied Ecology, v. 12, p. 367-380.

Shuttleworth, W.J., and Calder, I.R., 1979, Has the PriestleyTaylor equation any relevance to forest evaporation?: Journal of Applied Meteorology, v. 18, p. 639-646.

Stewart, J.B., 1977, Evaporation from the wet canopy of a pine forest: Water Resources Research, v. 13, p. 915-921.

Topp, G.C., Davis, J.L., and Annan, A.P., 1980, Electromagnetic determination of soil water content: Measurements in coaxial transmission lines: Water Resources Research, v. 16, p. 574-582.

U.S. Bureau of the Census, 1992, 1990 Census of population and housing, in Summary Tape File 1A on CD-ROM: Washington D.C., U.S. Bureau of the Census.

U.S. Department of Agriculture, 1975, Soil taxonomy-a basic system of soil classification for making and interpreting soil surveys: U.S. Department of Agriculture, Soil Conservation Service Handbook 436, $754 \mathrm{p}$.

Vaccaro, J.J., Hansen, A.J., Jr., and Jones, M.A., 1998, Hydrogeologic framework of the Puget Sound Aquifer System, Washington, and British Columbia: U.S. Geological Survey Professional Paper 1424-D, 77 p.

Wiggins, W.D., Ruppert, G.P., Smith, R.R., Reed, L.L., Hubbard, L.E., and Courts, M.L., 1996, Water resources data, Washington, water year 1995: U.S. Geological Survey Water-Data Report WA-95-1, 456 p.

1997, Water resources data, Washington, water year 1996: U.S. Geological Survey Water-Data Report WA-96-1, 494 p. 
